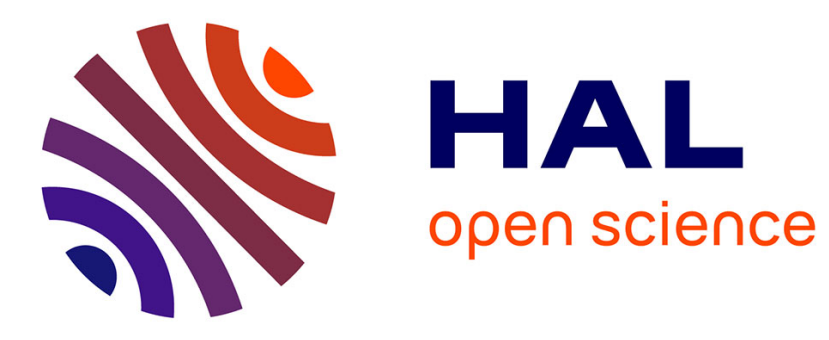

\title{
Pyrenoidal sequestration of cadmium impairs carbon dioxide fixation in a microalga
}

\author{
Florent Penen, M.-P. Isaure, Dirk Dobritzsch, Etienne Gontier, Hiram
}

Castillo-Michel, Philippe Le Coustumer, Julien Malherbe, Dirk Schaumlöffel

\section{- To cite this version:}

Florent Penen, M.-P. Isaure, Dirk Dobritzsch, Etienne Gontier, Hiram Castillo-Michel, et al.. Pyrenoidal sequestration of cadmium impairs carbon dioxide fixation in a microalga. Plant, Cell and Environment, 2020, 43 (2), pp.479-495. 10.1111/pce.13674 . hal-02399338

\section{HAL Id: hal-02399338 \\ https://hal.science/hal-02399338}

Submitted on 9 Dec 2020

HAL is a multi-disciplinary open access archive for the deposit and dissemination of scientific research documents, whether they are published or not. The documents may come from teaching and research institutions in France or abroad, or from public or private research centers.
L'archive ouverte pluridisciplinaire $\mathbf{H A L}$, est destinée au dépôt et à la diffusion de documents scientifiques de niveau recherche, publiés ou non, émanant des établissements d'enseignement et de recherche français ou étrangers, des laboratoires publics ou privés. 
4 Florent Penen ${ }^{1}$, Marie-Pierre Isaure ${ }^{1}$, Dirk Dobritzsch ${ }^{2}$, Hiram Castillo-Michel ${ }^{3}$, Etienne 5 Gontier $^{4}$, Philippe Le Coustumer ${ }^{1,4,5}$, Julien Malherbe ${ }^{1}$, Dirk Schaumlöffel ${ }^{1 *}$

6

$7{ }^{1}$ CNRS / Université de Pau et des Pays de l'Adour / E2S UPPA, Institut des Sciences

8 Analytiques et de Physico-Chimie pour l'Environnement et les Matériaux, UMR 5254, 64000

9 Pau, France

10

11

\section{fixation in a microalga ${ }^{\#}$}

${ }^{2}$ Martin-Luther-Universität Halle-Wittenberg, Core Facility Proteomic Mass Spectrometry, Proteinzentrum Charles Tanford, Kurt-Mothes-Str. 3a, 06120 Halle (Saale), Germany

${ }^{3}$ ID21 Beamline, European Synchrotron Radiation Facility (ESRF), BP220, 38043 Grenoble, France

${ }^{4}$ Université de Bordeaux, Bordeaux Imaging Center UMS 3420 CNRS - US4 INSERM, Pôle d'imagerie électronique, 146 rue Léo Saignat, 33076 Bordeaux, France

${ }^{5}$ Université de Bordeaux, UF Sciences de la Terre et Environnement, Allée G. Saint-Hillaire, 33615 Pessac, France

\section{\#Accepted manuscript :}

Penen, F., Isaure, M.-P., Dobritzsch, D., Castillo, H., Gontier, E., Le Coustumer, P., Malherbe, J., Schaumlöffel, D. (2020). Pyrenoidal sequestration of cadmium impairs carbon dioxide fixation in a microalga. Plant, Cell \& Environment, 43, 479-495 https://doi.org/10.1111/pce.13674 
*Corresponding author:

Dirk Schaumlöffel

CNRS / Université de Pau et des Pays de l'Adour / E2S UPPA, Institut des Sciences

31 Analytiques et de Physico-Chimie pour l'Environnement et les, Matériaux, UMR 5254, 64000

32 Pau, France

33 Tel: $(+33) 559407760$

34 E-mail adress: dirk.schaumloeffel@univ-pau.fr

\section{ABSTRACT}

36 Mixotrophic micro-organisms are able to use organic as well as inorganic carbon sources and,

37 thus, play an essential role in the biogeochemical carbon cycle. In aquatic ecosystems, the alteration of $\mathrm{CO}_{2}$ fixation by toxic metals such as cadmium - classified as a priority pollutant could contribute to the unbalance of the carbon cycle. In consequence, the investigation of cadmium impact on carbon assimilation in mixotrophic micro-organisms is of high interest.

41 We exposed the mixotrophic microalga Chlamydomonas reinhardtii to cadmium in a growth medium containing both $\mathrm{CO}_{2}$ and labeled ${ }^{13} \mathrm{C}-[1,2]$ acetate as carbon sources. We showed that the accumulation of cadmium in the pyrenoid, where it was predominantly bound to sulfur ligands, impaired $\mathrm{CO}_{2}$ fixation to the benefit of acetate assimilation. TEM/X-EDS and $\mu \mathrm{XRF} / \mu \mathrm{XANES}$ at $\mathrm{Cd} \mathrm{L}_{\mathrm{III}}$-edge indicated the localization and the speciation of cadmium in the cellular structure. In addition, NanoSIMS analysis of the ${ }^{13} \mathrm{C} /{ }^{12} \mathrm{C}$ ratio in pyrenoid and starch granules revealed the origin of carbon sources. The fraction of carbon in starch originating from $\mathrm{CO}_{2}$ decreased from $73 \%$ to $39 \%$ during cadmium stress. For the first time, the complementary use of high-resolution elemental and isotopic imaging techniques allowed relating the impact of cadmium at the subcellular level with carbon assimilation in a mixotrophic microalga. 


\section{KEYWORDS}

53 Biogeochemical carbon cycle, $\mathrm{CO}_{2}$ fixation, toxic metals, cadmium stress, subcellular imaging,

54 NanoSIMS, synchrotron $\mu \mathrm{XRF}, \mu \mathrm{XANES}$, TEM/X-EDS, isotopic labeling, isotope ratio

\section{INTRODUCTION}

The increase of carbon dioxide concentration in the atmosphere over the past decades has been associated with global climate change. Therefore, investigation and understanding of the biogeochemical carbon cycle is of primordial importance. The terrestrial and oceanic biosphere plays a major role in the global carbon cycle by the production and conversion of organic matter (Field, Behrenfeld, Randerson \& Falkowski, 1998). Plants have developed a process for $\mathrm{CO}_{2}$ fixation into organic carbon using the enzyme ribulose-1,5-bisphosphate carboxylase/oxygenase (RuBisCO) which is regarded to be the most abundant protein in the biosphere (Ellis, 1979). Microalgae are small eukaryotic organisms where RuBisCO is concentrated in the specific organelle called the pyrenoid (Badger et al., 1998). Pyrenoid containing algae have been identified as being responsible for $28-44 \%$ of the global carbon fixation which underlines the key role of microalgae in the biogeochemical carbon cycle (Mackinder et al., 2016).

Eukaryotic algae are classically considered as photoautotrophic using light and inorganic compounds for energy and carbon fixation, or heterotrophic using only organic compounds. Recently, mixotrophy has been integrated into aquatic biogeochemical cycle modeling (Caron, 2016; Ward \& Follows, 2016). Mixotrophic organisms are able to combine photoautotrophic growth conditions as well as heterotrophic nutrition. They are dominant among micro-algal communities in oligotrophic and eutrophic environments (Burkholder, Glibert \& Skelton, 
2008; Hartmann et al., 2012). To date, the consideration of mixotrophy in biogeochemical carbon cycle models is still at the beginning (Caron, 2016). Recently it has been shown that mixotrophy globally lead to an increase of the size of organisms in the aquatic food chain and thus enhances carbon sinking into the deep ocean by 35\% (Ward \& Follows, 2016).

Cadmium is a highly toxic metal and is considered as a priority pollutant in ecosystems (Campbell, 2006). In high polluted natural waters micromolar cadmium concentrations were found such as in the Tinto river in Spain $(40-620 \mu \mathrm{M})$ (Aguilera \& Amils, 2005) while for other natural waters lower $\mathrm{Cd}$ concentration are described, e.g. $2.4-17.8 \mathrm{nM}$ in polluted Macedonian rivers (Ramani et al., 2014) and only 0.2 - $2 \mathrm{nM}$ in a Swiss river (Xue \& Sigg, 1998). Also, in polluted soils and soil solutions high cadmium concentrations were measured, for example, $5.4-45.5 \mu \mathrm{M} \mathrm{Cd}$ in soil solutions of soils close to a chemical engineering plant in Northern Taiwan (Lee, Lai \& Chen, 2004) and $284 \mathrm{mg} \mathrm{Cd}$ per $\mathrm{kg}$ in paddy soils from Thailand (Simmons, Pongsakul, Saiyasitpanich \& Klinphoklap, 2005). Moreover, Cd has been shown to be biomagnified in some aquatic food webs (Croteau, Luoma \& Stewart, 2005; Ikemoto et al., 2008; Rouleau, Gobeil \& Tjlve, 2006; Signa, Mazzola, Tramati \& Vizzini, 2017). At the microbial level, this accumulation occurs in communities between bacteria and eukaryote organisms (Worden et al., 2015). In view of the importance of mixotrophy in the aquatic carbon cycle, the impact of toxic metals such as $\mathrm{Cd}$ on carbon assimilation in microalgae is of growing interest.

Chlamydomonas reinhardtii is a unicellular green alga which is found worldwide in soils and fresh water as its natural habitat. This alga is used as a model for many cellular processes (Dent, Han \& Niyogi, 2001; Goto \& Johnson, 1995; Harris, 1989; Merchant et al., 2006; Merchant, Kropat, Liu, Shaw \& Warakanont, 2012; Merchant et al., 2007; Rochaix, M. GoldschmidtClermont \& Merchant, 1998; Silflow \& Lefebvre, 2001) including metallic stress (Hanikenne, 
2003). Cadmium is known to inhibit its sexual reproduction (Goodenough et al., 1993), to limit

100 photosynthesis activity (Faller, Kienzler \& Krieger-Liszkay, 2005; Nagel \& Voigt, 1989, 1995;

101 Voigt \& Nagel, 2002; Voigt, Nagel \& Wrann, 1998) and to induce oxidative stress (Aksmann

102 et al., 2014; Vega, Garbayo, Domínguez \& Vigara, 2006). In order to reduce free intracellular

$103 \mathrm{Cd}^{2+}$, the microalga synthesizes thiol peptides such as phytochelatins (Bräutigam,

104 Schaumlöffel, Preud'Homme, Thondorf \& Wesenberg, 2011; Gekeler, Grill, Winnacker \&

105 Zenk, 1988) and sequesters Cd bound to polyphosphate granules into vacuoles which were

106 compared to acidocalcisomes (Penen et al., 2017; Ruiz, Marchesini, Seufferheld, Govindjee \&

107 Docampo, 2001).

108 C. reinhardtii can grow photoautotrophically in the presence of light and $\mathrm{CO}_{2}$,

109 heterotrophically in the dark when acetate is available as an organic carbon source or

110 mixotrophically with acetate, $\mathrm{CO}_{2}$ and light (Johnson \& Alric, 2013). In the latter case, $\mathrm{CO}_{2}$ is

111 photosynthetically fixed by RuBisCO (Johnson \& Alric, 2012, 2013), while non-

112 photosynthetic acetate assimilation begins by its incorporation into acetyl coenzyme A

113 (acetylCoA) (Johnson \& Alric, 2012, 2013). Then, acetylCoA is metabolized in the

114 tricarboxylic acid (TCA) cycle in mitochondria or in the glyoxylate cycle in cytosol (Johnson

115 \& Alric, 2012, 2013; Singh, Shukla, Chary \& Rao, 2014). Both acetate assimilation and

116 photosynthesis lead to starch formation (Ball, Dirick, Decq, Martiat \& Matagne, 1990; Heifetz,

117 Förster, Osmond, Giles \& Boynton, 2000; Johnson \& Alric, 2012, 2013; Park et al., 2015). In

118 spite of an abundant literature about carbon assimilation under mixotrophic conditions in $C$.

119 reinhardtii, the impact of toxic metals on the carbon metabolism has not been investigated yet.

120 Ion beam and X-ray beam imaging techniques are powerful tools to study the isotopic and

121 elemental composition of single-cells (Ortega, Devès \& Carmona, 2009; Penen et al., 2016;

122 Roschzttardtz et al., 2011; Sarret et al., 2013; Schaumlöffel et al., 2016). Nanoscale secondary 
123 ion mass spectrometry (NanoSIMS) allows elemental and isotopic mapping with a resolution

124 of about $50 \mathrm{~nm}$. In biology, it is used to localize and to determine at a subcellular level the 125 turnover of proteins and metabolites using stable isotopic tracers $\left({ }^{13} \mathrm{C}\right.$ and $\left.{ }^{15} \mathrm{~N}\right)(\mathrm{Gao}$, Huang \& 126 Tao, 2016; Lechene et al., 2006). Moreover, when NanoSIMS is combined with transmission 127 electron microscopy (TEM) in correlative imaging, isotopic tracers can be localized in the cell 128 structure (Clode, Stern \& Marshall, 2007; Hoppe, Cohen \& Meibom, 2013; Kopp et al., 2015; 129 Penen et al., 2016). NanoSIMS mapping has been also used to determine metal distributions in 130 plants and microalgae (Hong-Hermesdorf et al., 2014; Moore et al., 2010, 2011, 2012). As 131 complementary techniques, synchrotron micro X-ray fluorescence ( $\mu \mathrm{XRF}$ ) and micro X-ray 132 absorption spectroscopy ( $\mu$ XAS) can be combined and directly applied on frozen hydrated 133 samples to locate metals and decipher their structural environment, respectively, allowing the 134 determination of metal distribution and speciation in subcellular regions of microalgae (Adams et al., 2016; Leonardo et al., 2014; Leonardo et al., 2016; Penen et al., 2017; Wang, Lv, Ma \& 136 Zhang, 2016).

137 Here, we investigated the impact of cadmium on carbon assimilation in C. reinhardtii grown 138 under mixotrophic conditions. The objective was to relate subcellular cadmium localization 139 and speciation with acetate and $\mathrm{CO}_{2}$ assimilation. Microalgae were thus exposed up to $70 \mu \mathrm{M}$ $140 \mathrm{Cd}$ and cultivated in the presence of labeled ${ }^{13} \mathrm{C}-[1,2]$ acetate to distinguish carbon originating 141 from acetate assimilation or from photosynthesis. A multimodal approach at subcellular level 142 allowed the localization of cadmium in the algal structure by TEM/X-EDS (X-ray energy 143 dispersive spectroscopy) and the determination of carbon origins by measuring the ${ }^{13} \mathrm{C} /{ }^{12} \mathrm{C}$ ratio 144 in the pyrenoid and starch using NanoSIMS. In addition, Cd was localized by $\mu$ XRF, which was combined to $\mu$ XANES (micro X-ray absorption near edge structure spectroscopy) at the

146 Cd L LII-edge to identify Cd speciation. Our study showed that in C. reinhardtii cadmium 147 sequestration in the pyrenoid impaired $\mathrm{CO}_{2}$ fixation to the benefit of acetate assimilation. 
149 Biological material and growth conditions

150 Chlamydomonas reinhardtii wild type strain (SAG 11/32b, Experimental Phycology and

151 Culture Collection of Algae at Goettingen University (EPSAG), Germany) was grown

152 heterotrophically in a tris-acetate-phosphate medium (Harris, 1989) where

153 ethylenediaminetetraacetic acid (EDTA) and $\mathrm{FeSO}_{4} \cdot 7 \mathrm{H}_{2} \mathrm{O}$ were replaced by iron

154 ethylenediamine-N,N'-bis(2-hydroxyphenylacetate) (Fe-EDDHA) to increase the availability

155 of cadmium in solution. All chemicals and reagents were purchased from Sigma-Aldrich

156 (Saint-Quentin Fallavier, France) unless stated otherwise. The composition of this TAPEDDHA

157 medium is described in Table $\mathrm{S} 1$. For carbon fixation experiments, the TAP $\mathrm{EDDHA}\left({ }^{13} \mathrm{C}\right)$ medium

158 was prepared with ${ }^{13} \mathrm{C}$-labeled acetate (sodium ${ }^{13} \mathrm{C}-[1,2]$ acetate, 99\% ${ }^{13} \mathrm{C}$, Sigma Aldrich)

159 instead of acetic acid and $\mathrm{pH}$ was equilibrated to 7 with a $\mathrm{HCl}$ solution. Microalgae grew at 22

$160{ }^{\circ} \mathrm{C}$ under constant illumination (by one Osram 827 and two Osram 840 fluorescent tubes) and

161 constant agitation (120 rpm). Fresh medium was inoculated with stock culture at the end of

162 exponential phase to reach an initial optical density at $730 \mathrm{~nm}\left(\mathrm{OD}_{730 \mathrm{~nm}}\right)$ of 0.040 . Micro-algae

163 were exposed to $10,20,30,40,50$ and $70 \mu \mathrm{M}$ of $\mathrm{CdCl}_{2}$ added $24 \mathrm{~h}$ after the inoculation while

164 control cultures were grown in parallel without $\mathrm{Cd}$ exposure (control). For controls and each

165 Cd concentration three independent algal cultures were grown (triplicates) and used for

166 replicated determination of the growth rate, chlorophyll and starch concentrations, and

167 cadmium uptake.

168 As the main aim of this study was the investigation of the cadmium stress response at cellular

169 level during the exponential growth phase, cells were exposed to Cd after $24 \mathrm{~h}$. Therefore

170 changes in the lag phase, the delay before the start of exponential growth, were not assayed

171 since this delay allowed the adaptation required for cells to begin the experience of new 
172 environmental conditions, i.e. cadmium exposure in this study. The cell cycle of $C$. reinhardtii

173 is about $24 \mathrm{~h}$ which is confirmed with the start of the exponential phase at this time point. This

174 means that under these conditions the cells of the second (and third) cell cycle are exposed.

175 Cells were harvested after $72 \mathrm{~h}$ for different analyses, i.e. at the end of the third cell cycle when

176 these cells experienced similar exposure conditions. It is a good approximation although

177 cultivation was not synchronized. This procedure also applied in our previous studies

178 (Bräutigam, Schaumlöffel, Preud'Homme, Thondorf, \& Wesenberg, 2011; Bräutigam,

179 Schaumlöffel, Krauss, \& Wesenberg, 2009; Penen et al., 2017).

180 The concentrations of free metals in the medium were simulated (Table 1) with the freeware

181 Visual MINTEQ 3.0 (vminteq.lwr.kth.se/visual-minteq-ver-3-0/) (Gustafsson, 2013) using

182 Lindsay's database containing thermodynamic equilibrium constants compiled by Lindsay

183 (1979). Before use, glassware was washed with $5 \% \mathrm{HNO}_{3}$. All solutions were prepared with 184 ultrapure water $\left(18 \mathrm{M} \Omega \mathrm{cm}\right.$ at $25^{\circ} \mathrm{C}$ ) obtained from a Milli- Q system (Millipore, Bedford, 185 MA).

186 Growth rate determination

187 Optical density at $730 \mathrm{~nm}\left(\mathrm{OD}_{730 \mathrm{~nm}}\right)$ was measured every $12 \mathrm{~h}$ in each control and Cd-exposed 188 algal cultures, grown in triplicate, using a spectrophotometer. Growth rates $\mu$ were calculated 189 as follows: $\mu=\left(\ln \mathrm{N}_{\mathrm{f}}-\ln \mathrm{N}_{\mathrm{i}}\right) / \Delta \mathrm{t} . \mathrm{N}_{\mathrm{f}}$ was the $\mathrm{OD}_{730 \mathrm{~nm}}$ of the culture measured at the end of the 190 exponential phase. $\mathrm{N}_{\mathrm{i}}$ was the $\mathrm{OD}_{730 \mathrm{~nm}}$ of the culture at the beginning of the exponential phase 191 and $\Delta \mathrm{t}$ was the duration of the exponential phase (in days). Relative growth rate was expressed 192 as the ratio $\mu / \mu_{0}$ determined during the exponential phase of growth ( $\mu$ : growth rate during 193 cadmium exposure, $\mu_{0}$ : growth rate in control conditions). The Excel macro REGTOX 194 (http://www.normalesup.org/ vindimian/en_index.html) was used to calculate the half 195 maximal efficient concentrations ( EC $\left._{50}\right)$ applying the Hill model. 
197 The chlorophyll concentration assay was adapted from Arnon et al. (Arnon, 1949). After $72 \mathrm{~h}$

198 cultivation, $1 \mathrm{ml}$ of each control and Cd-exposed algal cultures (grown in triplicate) was

199 centrifuged at $13000 \times \mathrm{g}$ for $1 \mathrm{~min}$. Each algal pellet was resuspended in $1 \mathrm{~mL}$ of $80 \%$ acetone

200 and vortexed for 2 min. Then, solubilized chlorophyll was separated from cell debris by a

201 centrifugation at $13000 \times \mathrm{g}$ for $4 \mathrm{~min}$. After that, the concentration $(\mathrm{C})$ of chlorophyll $\mathrm{a}$ and $\mathrm{b}$

202 in the culture medium was determined spectrophotometrically at $652 \mathrm{~nm}$ and calculated as

203 follows: $\mathrm{C}=\mathrm{Abs} 652 \mathrm{~nm} \times 1000 / 34.5$ with $\mathrm{C}$ in $\mathrm{mg} \mathrm{mL}^{-1}$. Finally, in order to relate the chlorophyll

204 content to the biomass, the determined chlorophyll concentration was normalized to the optical

205 density at $730 \mathrm{~nm}$ whose value is proportional to the number of cells in the medium (unit: $\mu \mathrm{g}$

$\left.206 \mathrm{~mL}^{-1} \mathrm{OD}_{730 \mathrm{~nm}^{-1}}\right)$.

\section{Starch concentration measurement}

208 After 72 h cultivation, microalgae were harvested from in triplicate grown control and Cd-

209 exposed $(70 \mu \mathrm{M})$ algal cultures by centrifugation at $3000 \times \mathrm{g}$ for 3 min and each pellet was

210 resuspended in $1.5 \mathrm{~mL}$ water. In order to estimate the dry biomass, a $0.5 \mathrm{~mL}$ aliquot from each

211 sample was dried at $60{ }^{\circ} \mathrm{C}$ for $24 \mathrm{~h}$ and the resulting pellet was weighted. The remaining $1 \mathrm{~mL}$

212 samples were washed once with water and once with $80 \%$ ethanol, and centrifuged $(3000 \times \mathrm{g}$

213 for $3 \mathrm{~min}$ ). Then, each pellet was boiled in $2 \mathrm{~mL}$ water for $10 \mathrm{~min}$. Finally, starch concentrations

214 were determined in these extracts, using the enzymatic starch assay kit HK (Sigma Aldrich)

215 described in Delrue et al. ( 1992).

\section{Cadmium uptake}

217 After $48 \mathrm{~h}$ cadmium exposure $(70 \mu \mathrm{M})$, microalgae were harvested from in triplicate grown

218 cultures by centrifugation at $3000 \times \mathrm{g}$ for $3 \mathrm{~min}$. In order to obtain the intracellular $\mathrm{Cd}$ 
219 concentration, each algal pellet was subjected to the following washing protocol according to 220 Macfie et al. (1994): a first time in water, then twice in a mix of $\mathrm{Na}_{2}-\mathrm{EDTA}(1 \mathrm{mM}) / \mathrm{CaCl}_{2}$

221 (3.77 $\mathrm{mM})$ and finally in water with centrifugation between in $(3000 \times \mathrm{g}$ for $3 \mathrm{~min})$. The 222 remaining pellets were dried at $60^{\circ} \mathrm{C}$ for $24 \mathrm{~h}$ and weighted. This dry algal biomass was 223 digested in a mixture of $1 \mathrm{~mL} \mathrm{70 \%} \mathrm{(v/v)} \mathrm{HNO}_{3}$ and $1 \mathrm{~mL} \mathrm{30 \% (v/v)} \mathrm{H}_{2} \mathrm{O}_{2}$ at $80{ }^{\circ} \mathrm{C}$ for $3 \mathrm{~h}$.

224 Samples were then diluted to reach a $2 \% \mathrm{HNO}_{3}$ concentration. The cadmium concentration 225 was determined by ICP-MS (Inductively Coupled Plasma Mass Spectrometry, 7500 model, 226 Agilent Technologies).

\section{Sample preparation for TEM/X-EDS and NanoSIMS}

Microalgae from a control and a Cd-exposed $(70 \mu \mathrm{M})$ culture containing ${ }^{13} \mathrm{C}$-labeled acetate in the medium were harvested after $72 \mathrm{~h}$ of inoculation by centrifugation at $3,000 \times \mathrm{g}$ for $3 \mathrm{~min}$. A protocol including high pressure freezing, and freeze substitution followed by resin inclusion was used to preserve cell integrity. For high-pressure freezing, each microalgae pellet was resuspended and incubated for $1 \mathrm{~h}$ in $150 \mathrm{mM}$ mannitol. After a centrifugation at $3000 \times \mathrm{g}$ for $3 \mathrm{~min}$, the harvested cells were included in agarose $2 \%$. Then, the inclusion was plunged in cryo-protectant 1-hexadecene and high-pressure freezing was performed immediately (EM HPM 100, Leica Microsystems, Vienna, Austria). Samples were maintained in liquid nitrogen until the freeze-substitution steps.

238 Freeze-substitution was adapted from O'Toole's protocol (O'Toole, 2010). Under liquid nitrogen, algal samples were post-fixed in $1 \%$ osmium tetroxide, $0.1 \%$ uranyl acetate and $0.25 \%$ glutaraldehyde in anhydrous acetone and transferred into the Automatic Freeze

241 Substitution System AFS2 (Leica microsystems). Temperature was maintained at $-90{ }^{\circ} \mathrm{C}$ for 3 
$242 \mathrm{~d}$ and then warmed to $-30{ }^{\circ} \mathrm{C}$ for $8 \mathrm{~h}$. Samples were removed from freeze-substitution system,

243 kept at $0{ }^{\circ} \mathrm{C}$ for $1 \mathrm{~h}$ and washed with water-free acetone.

244 Resin inclusion was carried out at room temperature. Samples were embedded in epoxy resin

245 (EPON 812, Delta Microscopies, Mauressac, France) using a graded resin and acetone series.

246 The following steps were applied for infiltration: 3:1 acetone:resin, 1:1 acetone:resin, 1:3

247 acetone:resin, and 2 baths with 100\% resin. Finally, resin embedded samples were polymerized

248 for $48 \mathrm{~h}$ at $60{ }^{\circ} \mathrm{C}$.

249 Samples were cut in $70 \mathrm{~nm}$ and $300 \mathrm{~nm}$ sections for TEM and NanoSIMS, respectively, using

250 a diamond knife (Diatome, Biel-Bienne, Switzerland) on an ultra-microtome [EM Ultracut-

251 UC7, Leica Microsystems) and placed on the respective sample holder. In order to carry out

252 correlative imaging by TEM and NanoSIMS, a first $70 \mathrm{~nm}$ section was placed on a copper grid

253 for TEM and then, an adjacent $300 \mathrm{~nm}$ section was placed on a silicon wafer (Wafer Solution,

254 Le Bourget du lac, France) for NanoSIMS as previously described (Penen et al., 2016). Cells

255 were localized and observed first by TEM and then, relocalized and analyzed by NanoSIMS.

\section{TEM/X-EDS analysis}

257 A transmission electron microscope FEI TECNAI 12 (Eindhoven, The Netherlands) using an 258 accelerating voltage $120 \mathrm{kV}$ and equipped with an X-Energy Dispersive Spectroscopy (X-Flash

259 6T 60 BRUKER-SYNERGIE 4, Evry, France) was used. The parallel electron beam of the

260 nanoprobe was focused on $0.25-1.2 \mu \mathrm{m}$ areas. Under these conditions X-EDS spectra of 1-2k

261 counts $\mathrm{s}^{-1}$, a deadtime of $15-20 \%$ and analytical time of $120-240 \mathrm{~s}$ per spectrum were 262 generated.

\section{NanoSIMS analysis}


264 A nanoscale secondary ion mass spectrometer NanoSIMS 50L (CAMECA, Gennevilliers, 265 France) was used to perform SIMS analysis. This device was equipped with a primary $\mathrm{Cs}^{+}$ion

266 source (lateral resolution down to $50 \mathrm{~nm}$ ) for the mapping of electronegative elements, and 267 with a novel $\mathrm{O}^{-}$RF plasma primary ion source enabling a high sensitivity for electropositive 268 elements combined to a high lateral resolution (40 $\mathrm{nm}$ lateral resolution) (Malherbe et al., 269 2016). The seven parallel electron multiplier detectors equipped on the NanoSIMS 50L instrument allowed detection of seven elements at the same time. In order to remove major interferences on the chosen element masses, the mass resolution $(M / \Delta M)$ was tuned to be about 5000. Initially, ion maps (256×256 pixels, $\left.64-144 \mu \mathrm{m}^{2}\right)$ of ${ }^{12} \mathrm{C}^{-},{ }^{13} \mathrm{C}^{-},{ }^{12} \mathrm{C}^{14} \mathrm{~N}^{-}$(for $\mathrm{N}$ detection) and ${ }^{32} \mathrm{~S}^{-}$were carried out using the primary $\mathrm{Cs}^{+}$ion source. Mapping of ${ }^{31} \mathrm{P}^{+}$and ${ }^{40} \mathrm{Ca}^{+}$was then performed using the $\mathrm{O}^{-} \mathrm{RF}$ plasma primary ion source.

\section{NanoSIMS data processing}

Image processing was performed using ImageJ software (v.1.48, Wayne Rasband, National Institutes of Health (NIH), Bethesda, MD, USA). Processing of NanoSIMS images required additionally the openMIMS plugin developed at the National Resource for Imaging Mass Spectrometry (NRIMS, Cambridge, MA, USA). Ion maps were corrected for detector dead 280 time (44 ns) with the openMIMS plugin and the ${ }^{13} \mathrm{C} /{ }^{12} \mathrm{C}$ ratio maps were corrected for the mass 281 bias as a function of the ${ }^{13} \mathrm{C} /{ }^{12} \mathrm{C}$ ratio measured on microalgae not enriched in ${ }^{13} \mathrm{C}$. The ${ }^{13} \mathrm{C} /{ }^{12} \mathrm{C}$ ratio was measured in regions of interest (ROI) defined on pyrenoid and starch granules of six control cells and six Cd-exposed cells as detailed in Figure S1. The isotopic enrichment of ${ }^{13} \mathrm{C}$ was expressed as its relative abundance $\delta^{13} \mathrm{C}$ compared to the ${ }^{13} \mathrm{C}$ natural isotopic abundance and calculated using the following formula:

$$
\delta^{13} \mathrm{C}=\frac{\mathrm{R}_{\text {sample }}}{\mathrm{R}_{\text {nat }}}-1
$$


287 where $\mathrm{R}_{\text {sample }}$ is the measured ${ }^{13} \mathrm{C} /{ }^{12} \mathrm{C}$ ratio in the $\mathrm{ROI}$ of the cells and $\mathrm{R}_{\text {nat }}$ is the natural carbon 288 isotope ratio.

289 The origin of carbon in starch granules from either acetate or $\mathrm{CO}_{2}$ as carbon source was

290 determined by data processing adapted from Terrado et al. (2017). First, the fractional

291 abundance $\mathrm{F}_{\text {starch }}$ of the carbon isotope ${ }^{13} \mathrm{C}$ in starch granules of the sum of both carbon isotopes

292 is given as (in percentage):

$$
\mathrm{F}_{\text {starch }}=\frac{{ }^{13} \mathrm{C}}{{ }^{13} \mathrm{C}+{ }^{12} \mathrm{C}} \times 100
$$

294 which can also be expressed as

$$
\mathrm{F}_{\text {starch }}=\frac{\mathrm{R}_{\text {starch }}}{1+\mathrm{R}_{\text {starch }}} \times 100
$$

where $\mathrm{R}_{\text {starch }}$ is the ${ }^{13} \mathrm{C} /{ }^{12} \mathrm{C}$ ratio measured in the ROI within starch granules. Then, the origin of starch carbon was determined using the following formulas:

$$
\mathrm{F}_{\text {starch }}=F_{\text {acetate }} \times f_{\text {acetate }}+F_{\mathrm{CO} 2} \times f_{\mathrm{CO} 2}
$$

$$
\text { with: } \quad f_{\text {acetate }}+f_{\mathrm{CO} 2}=1
$$

$$
f_{\text {acetate }}=\frac{F_{\text {starch }}-F_{\mathrm{CO} 2}}{F_{\text {acetate }}-F_{\mathrm{CO} 2}} \times 100 \text { and } f_{\mathrm{CO} 2}=\frac{\mathrm{F}_{\text {starch }}-F_{\text {acetate }}}{F_{\mathrm{CO} 2}-F_{\text {acetate }}} \times 100
$$

301 The formula (6) results from (4) and (5) where $F_{\text {acetate }}$ and $F_{\mathrm{CO} 2}$ are the fractional abundance of

$302{ }^{13} \mathrm{C}$ in the carbon sources acetate $(99 \%)$ and $\mathrm{CO}_{2}(1.09 \%)$, respectively, and $f_{\text {acetate }}$ and $f_{\mathrm{CO} 2}$ 303 represent the percentage of the origin of carbon within the ROI (starch granule) from the 304 respective source.

\section{Samples preparation for synchrotron-based techniques}


306 Microalgae from a control and a Cd-exposed $(70 \mu \mathrm{M})$ culture were harvested after $72 \mathrm{~h}$ of 307 inoculation by centrifugation at $3000 \times \mathrm{g}$ for $3 \mathrm{~min}$. They were rapidly washed in ultrapure

308 water three times to remove metals and organic compounds weakly adsorbed on the cell wall.

309 Two sample preparations were used.

310 For $\mu \mathrm{XRF}$ and $\mathrm{Cd} \mathrm{L}_{\mathrm{III}}$-edge $\mu \mathrm{XANES}$, droplets of microalgae suspension were deposited on 4 $311 \mu \mathrm{m}$-thick Ultralene film (SPEX sample prep Metuche, NJ). After decantation for $10 \mathrm{~min}$, 312 microalgae were frozen into liquid nitrogen-chilled isopentane $\left(-160{ }^{\circ} \mathrm{C}\right)$.

313 For Cd LIII-edge XANES bulk analysis, the algae pellet was frozen in liquid nitrogen, 314 homogenized and pressed as a $5 \mathrm{~mm}$ frozen pellet. All the samples were kept frozen at $-80{ }^{\circ} \mathrm{C}$ 315 until measurements and transferred to the sample stage in their hydrated frozen state.

\section{$317 \quad \boldsymbol{\mu}$ XRF imaging}

318 Measurements were performed on the ID21 beamline at the European Synchrotron Radiation

319 Facility (ESRF, Grenoble, France) equipped with a fixed exit Si(111) two-crystal 320 monochromator (Cotte et al., 2017). The X-ray photons were focused by a KB mirror system 321 providing a sub-micron resolution of $0.6 \mu \mathrm{m}(\mathrm{H}) \times 0.3 \mu \mathrm{m}(\mathrm{V}) \mathrm{FWHM}$ on the sample. The Xray fluorescence signal was recorded with a large $100 \mathrm{~mm}^{2}$ SDD detector (Bruker) while the samples were scanned to obtain elemental maps. All the measurements were carried out under cryogenic conditions at $-160{ }^{\circ} \mathrm{C}$ using a liquid $\mathrm{N}_{2}$ cryostat to limit beam radiation damage. The fluorescence signal was normalized by the incident photon intensity $\left(\mathrm{I}_{0}\right)$ measured with a photodiode. Phosphorus, sulfur, chloride, and cadmium maps were recorded using an incident energy of $3570 \mathrm{eV}$, below the absorption edge of potassium, while potassium and calcium maps were recorded at $4100 \mathrm{eV}$ as described in Isaure et al. (2006). The fluorescence signal was 
329 deconvoluted from fluorescence background and fluorescence elemental overlapping to obtain

330 elemental maps using the PYMCA software (Solé, Papillon, Cotte, Walter \& Susini, 2007).

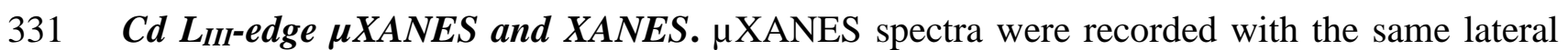

332 resolution as for $\mu \mathrm{XRF}$ in fluorescence mode on points of interest visualized on the $\mu \mathrm{XRF}$ 333 maps. For Cd model compounds and bulk samples, XANES spectra were recorded in

334 fluorescence mode with a defocused beam $(100 \mu \mathrm{m} \times 100 \mu \mathrm{m})$. Measurements were also done

335 under cryogenic conditions to limit radiation damage and speciation change. $\mu$ XANES and

336 XANES spectra were collected in the energy range 3520-3590 eV. Approximately 30 scans

337 were calibrated with a metallic Cd foil, averaged, and normalized according to standard

338 methods using ATHENA software (Ravel \& Newville, 2005). Then, experimental normalized

339 spectra were compared to a library of standard spectra previously collected (Huguet et al.,

340 2012; Isaure et al., 2006, 2015; Penen et al., 2017). A fingerprint approach was used to simulate

341 the unknown spectra by linear combination fits (LCFs) of Cd model compounds as described

342 by Isaure et al. (2006). The quality of the fits was estimated by the normalized sum-squares

343 residuals NSS $=\Sigma\left(\text { Xanesexperimental }- \text { Xanes }_{\text {fit }}\right)^{2} / \Sigma\left(\right.$ Xanesexperimental $^{2} \times 100$, in the $3520-3580$ for

$344 \mu$ XANES spectra and 3520-3590 eV range for XANES spectra. Linear combination fits with

345 one, two and three components were tested and the combination with $n+1$ components was

346 retained if the NSS parameter decreased more that $20 \%$ in comparison to the fit with $n$

347 components (Figure S2). The uncertainty of the proportion of each compound was estimated

348 to $10 \%$ (Isaure et al., 2015).

\section{Statistics}

350 One-way ANOVA followed by a post-hoc Tuckey test Statistical analyses were performed on

351 growth rate, chlorophyll concentration, starch concentration and ${ }^{13} \mathrm{C} /{ }^{12} \mathrm{C}$ ratio measured on

352 NanoSIMS maps to identify significant differences among the different conditions. Results 
353

354

355

356

357

358

359

360

361

362

were considered significant for a $p<0.05$. Kruskal-Wallis one-way analysis of variance on ranks $(\mathrm{p}<0.05)$ was performed when the condition of homogeneity of variances was not respected.

\section{RESULTS}

\section{Availability of cadmium and essential trace elements in TAPEDDHA medium}

In a first approach, cadmium availability in TAPEDDHA medium, i.e. free $\mathrm{Cd}^{2+}$ concentration, was simulated using Visual Minteq software (Table 1). Concentrations of 10, 20, 30, 40, 50 and $70 \mu \mathrm{M}$ of $\mathrm{CdCl}_{2}$ added to the medium correspond to free ionic Cd concentrations of 1,4 , 7, 10, 13 and $20 \mu \mathrm{M}$. Cd availability was thus increased by 10 compared to the classic TAP medium for the higher $\mathrm{Cd}$ concentration.

The free ion concentrations of several essential trace elements in the TAP $\mathrm{EDDHA}_{\mathrm{A}}$ medium were markedly different from that in the original TAP medium (Table 1). Most important, the concentration of free $\mathrm{Zn}^{2+}$ increased by 10000 and of free $\mathrm{Cu}^{2+}$ by 100 whereas $\mathrm{Co}^{2+}$ availability decreased by 10000 compared to the classic TAP medium.

\section{Cadmium exposure leads to starch accumulation}

C. reinhardtii was exposed to a range of $10-70 \mu \mathrm{M} \mathrm{CdCl}_{2}$ for $48 \mathrm{~h}$ in TAPEDDHA medium and relative growth rates were measured in order to determine $\mathrm{Cd}$ efficient concentrations $\left(\mathrm{EC}_{\mathrm{x}}\right)$ with the Hill model (Figure 1A). Up to $20 \mu \mathrm{M} \mathrm{Cd}$, no significant effect on the algae growth was observed $\left(\mathrm{EC}_{5}=22 \mu \mathrm{M} \mathrm{Cd}\left[15-31 \mu \mathrm{M} \mathrm{Cd} \mathrm{CI}{ }_{95 \%}\right]\right)$ but increasing Cd concentrations induced a strong decrease of the relative growth rate $\left(\mathrm{EC}_{50}=74 \mu \mathrm{M} \mathrm{Cd}\left[67-86 \mu \mathrm{M} \mathrm{Cd} \mathrm{CI} \mathrm{I}_{95}\right]\right)$. In order to investigate the impact of cadmium on C. reinhardtii in stress conditions, the $\mathrm{Cd}$ exposure concentration of $70 \mu \mathrm{M}$ (i.e. $20 \mu \mathrm{M}$ free $\mathrm{Cd}^{2+}$ ) was applied in this study since it was the nearest to $\mathrm{EC}_{50}$ value. These concentrations can seem quite high compared to other studies 
376 focused on Cd concentrations in the 10-100 $\mathrm{nM}$ range (Stoiber et al. 2012, Lavoie et al. 2012)

377 . However, contrary to these studies, the present experiments were carried out in mixotrophic 378 conditions, which likely modified the cell response. Our observations support that under 379 mixotrophic conditions $C$. reinhardtii was more resistant against Cd stress.

380 When exposed to $70 \mu \mathrm{M} \mathrm{Cd}$, the intracellular cadmium concentration was $1530 \pm 132 \mu \mathrm{g} \mathrm{g}^{-1}$

381 (dry weight). The global impact of this cadmium stress on C. reinhardtii vitality was examined 382 by the determination of growth rate, chlorophyll concentration and starch concentration (Figure 383 1B, C and D). Compared to the control condition, Cd induced a decrease of the growth rate 384 (from $0.76 \pm 0.05$ to $0.39 \pm 0.06 \mathrm{~d}^{-1}$ ) and the chlorophyll concentration (from $8.3 \pm 0.4$ to 6.4

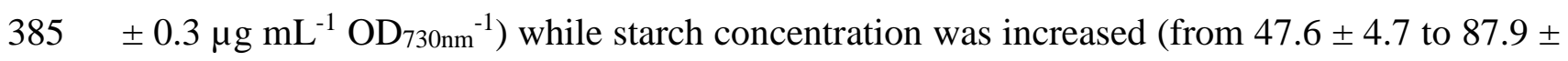
$38613.2 \mathrm{mg} \mathrm{g}^{-1}$ ). These results showed an important stress in C. reinhardtii when it exposed to 70 $387 \mu \mathrm{M}$ Cd leading to an impaired photosynthesis and an accumulation of starch. Carbon 388 metabolism in $C$. reinhardtii was thus strongly impacted by $\mathrm{Cd}$ toxicity.

\section{Cadmium sequestration in pyrenoid and vacuoles}

C. reinhardtii cells exposed to $70 \mu \mathrm{M}$ Cd for $48 \mathrm{~h}$ were examined by TEM/X-EDS and NanoSIMS (Figure 2). Figure $2 \mathrm{~A}$ and B show that cell structure was altered by Cd exposure, particularly the chloroplast where the pyrenoid and its starch shell were destructured. The starch plaques were also more abundant in the Cd-exposed cells corroborating the increase of starch measured by enzymatic digestion.

395 Elemental composition of organelles observed on TEM micrographs (Figure 2C, F) was determined on their corresponding NanoSIMS elemental maps (Figure 2E, H). Vacuoles were rich in calcium, phosphorus and sulfur. Pyrenoids were characterized by a composition rich in sulfur and nitrogen, which could be attributed to the high concentration in proteins (RuBisCO in particular) inside this organelle. Moreover, pyrenoids were surrounded by a halo of 
400 phosphorus which did not necessarily correspond to the starch shell. Finally, starch shells and 401 starch plates were rich in nitrogen.

402 Additional X-EDS analysis (Figure 2D, G) revealed that cadmium concentration was high in

403 the pyrenoid. This pyrenoidal sequestration of Cd could thus be responsible for Cd toxicity in

404 C. reinhardtii. Furthermore, Cd was localized beside $\mathrm{Ca}$ and $\mathrm{P}$ in electron dense bodies in

405 vacuoles suggesting a cadmium sequestration in calcium polyphosphate granules as confirmed 406 in our previous study by $\mu$ XANES analysis (Penen et al., 2017). It is important to note that the 407 elemental composition of vacuoles and pyrenoid determined by NanoSIMS was confirmed by 408 the X-EDS measurements.

409 Cadmium localized in pyrenoid is preferentially bound to sulfur ligands

410 Elemental $\mu \mathrm{XRF}$ maps (Figure 3A) of C. reinhardtii cells exposed to $70 \mu \mathrm{M}$ Cd for $48 \mathrm{~h}$ 411 corroborated the elemental distribution obtained by TEM/X-EDS and NanoSIMS analysis 412 (Figure 3A). A sulfur spot was present in each cell which corresponded to the pyrenoid. 413 Although cadmium was detected at low level in the whole cells, it was highly concentrated in 414 one spot in each cell co-localized with sulfur, confirming its pyrenoidal sequestration. In 415 addition, phosphorus, calcium, and to a lesser extent cadmium were co-localized in spots of 1 $416 \mu \mathrm{m}$ size representing Ca polyphosphate granules in vacuoles.

417 In combination with $\mu \mathrm{XRF}, \mu \mathrm{XANES}$ gave information about $\mathrm{Cd}$ binding ligands in areas of 418 interest evidenced by $\mu$ XRF. In contrast, XANES collected in bulk samples allowed to 419 determine the average in situ cadmium binding in the microalgae. Cd LIII-edge XANES was 420 demonstrated powerful to distinguish sulfur from oxygen ligands due to absence of a peak at $4213539 \mathrm{eV}$ in sulfur binding atoms (Isaure et al., 2006). Moreover, as indicated by arrows in Cd 422 reference XANES spectra in figures 3B and 3C, the second oscillation was shifted to higher 423 energy values for $\mathrm{Cd}$-acetate and $\mathrm{Cd}$-malate where $\mathrm{Cd}$ is bound to carboxyl groups compared 
424 to Cd bound to phosphate groups in Cd-phosphate and Cd-phytate (Penen et al., 2017). This enabled a differentiation between the oxygen donor ligands in Cd-carboxyl and Cd-phosphate. had similar pattern, thus hampering the exact determination of the nature of sulfur donor ligands; however, they can be encompassed as thiol groups. Therefore, the distribution of $\mathrm{Cd}$ ligands, as results of linear combination fits (LCFs) of Cd L LII-edge XANES and $\mu$ XANES spectra, was described as ratios of $\mathrm{Cd}-\mathrm{S}, \mathrm{Cd}-\mathrm{O}-\mathrm{P}$, and $\mathrm{Cd}-\mathrm{O}-\mathrm{C}$ compounds (Figure 3D).

In the $S$ and Cd-enriched areas attributed to the pyrenoid, $\mu$ XANES analysis revealed that $\mathrm{Cd}$ was mainly coordinated by thiol ligands $(67 \pm 10 \%$ and $56 \pm 10 \%$ for the two presented pyrenoids), but also by carboxyl groups (33 $\pm 10 \%$ and $44 \pm 10 \%)$. No phosphate ligand was identified in these spots. A pyrenoid consists principally of proteins, mainly RuBisCO, thus $\mu$ XANES results could indicate cadmium binding to protein thiol groups. Finally, Cd bound to carboxyl groups could be attributed to Cd sequestered to the starch shell around the pyrenoid since $\mu$ XANES here probed a three-dimensional volume.

XANES measurements of bulk samples showed that Cd- thiol ligands in algae accounted for $31 \pm 10 \%$ only while Cd- carboxyl groups amounted to $25 \pm 10 \%$. The main part of Cd was associated with phosphate ligands $(44 \pm 10 \%)$ suggesting that the calcium polyphosphate

441 granules sequestered an important part of the metal in C. reinhardtii. Indeed, these granules 442 were previously probed by $\mu$ XANES and revealed the sequestration of Cd by phosphate ligands 443 (Penen et al., 2017).

\section{Cadmium promotes carbon incorporation from acetate in starch}

445 In order to investigate the impact of $\mathrm{Cd}$ on carbon fixation and to distinguish inorganic and 446 organic carbon sources of $C$. reinhardtii, i.e. $\mathrm{CO}_{2}$ and acetate, ${ }^{13} \mathrm{C}$ labeled acetate was employed 
447 for tracer experiments. C. reinhardtii control cells and cells exposed to $70 \mu \mathrm{M} \mathrm{Cd}$ for $48 \mathrm{~h}$ in $448 \mathrm{TAP}_{\text {EDDHA }}$ medium containing ${ }^{13} \mathrm{C}$ labeled acetate were examined by NanoSIMS (Figure 4). $449{ }^{13} \mathrm{C} /{ }^{12} \mathrm{C}$ ratio maps highlight intracellular areas of carbon resulting from acetate assimilation 450 (high ${ }^{13} \mathrm{C} /{ }^{12} \mathrm{C}$ ratio) (Figure $4 \mathrm{~A}$ and $\mathrm{B}$ ).

451 Two different subcellular regions of interest (ROI) were selected in ${ }^{13} \mathrm{C} /{ }^{12} \mathrm{C}$ ratio maps (Figure $452 \mathrm{~S} 1$ ) to investigate carbon assimilation: the pyrenoid as organelle of $\mathrm{CO}_{2}$ fixation and the starch 453 plates as a final storage form of carbon in C. reinhardtii. Based on data from ROI in 6 individual 454 control cells and 6 exposed cells (Figure $\mathrm{S} 1$ ), the ${ }^{13} \mathrm{C}$ isotopic enrichment $\delta^{13} \mathrm{C}$ was calculated as represented in Figure 4C. Hence, ${ }^{13} \mathrm{C}$ enrichment was found in the pyrenoid, but it did not change significantly under $\mathrm{Cd}$ exposure. In contrast, starch plates showed a 5 -fold higher ${ }^{13} \mathrm{C}$ enrichment under $\mathrm{Cd}$ exposure than in unexposed cells. In particular, the study of carbon isotopic distribution in starch as the final carbon storage form allowed the quantification of carbon assimilation from $\mathrm{CO}_{2}$ and acetate sources.

The determination of $f_{\text {acetate }}$ and $f_{\mathrm{CO} 2}$ in starch granules revealed that, under control conditions, $73 \%$ of starch carbon came from $\mathrm{CO}_{2}\left({ }^{12} \mathrm{C}\right)$ and $27 \%$ from acetate $\left({ }^{13} \mathrm{C}\right)(\mathrm{RSD} \pm 9 \%)$. In contrast, $\mathrm{Cd}$ stress seemed to disturb $\mathrm{CO}_{2}\left({ }^{12} \mathrm{C}\right)$ assimilation which decreased to $39 \%$ while acetate $\left({ }^{13} \mathrm{C}\right)$ assimilation contributed for $61 \%$ of starch carbon (Figure 4D) (RSD $\pm 13 \%$ ). Moreover, when the isotopic distribution of starch carbon was combined with the starch 465 concentration previously analyzed (Figure 1D), it appeared that overall $\mathrm{CO}_{2}$ carbon $\left({ }^{12} \mathrm{C}\right)$ assimilation remained limited $\left(1.28 \pm 0.18 \mathrm{mmol}\left({ }^{12} \mathrm{C}\right) \mathrm{g}^{-1}\right.$ in control condition; $1.26 \pm 0.43$ mmol $\left({ }^{12} \mathrm{C}\right) \mathrm{g}^{-1}$ under $\mathrm{Cd}$ exposure) (Figure 4E) relative to the highly increased starch biosynthesis under $\mathrm{Cd}$ exposure. In contrast, acetate carbon $\left({ }^{13} \mathrm{C}\right)$ assimilation was about 4 -fold higher during $\mathrm{Cd}$ exposure $\left(0.48 \pm 0.15 \mathrm{mmol}\left({ }^{13} \mathrm{C}\right) \mathrm{g}^{-1}\right.$ under control conditions; $1.99 \pm 0.47$ mmol $\left({ }^{13} \mathrm{C}\right) \mathrm{g}^{-1}$ under $\mathrm{Cd}$ exposure). These results suggest that $\mathrm{Cd}$ exposure interfered with $\mathrm{CO}_{2}$ 
assimilation due to the Cd fixation in the pyrenoid possibly due to the $\mathrm{Cd}$ binding to protein thiol groups.

\section{DISCUSSION}

\section{Effect of the culture medium on cell vitality}

475 C. reinhardtii was cultivated in a modified version of TAP medium where EDTA was replaced 476 with EDDHA (TAP ${ }_{\text {EDDHA }}$ ) in order to increase $\mathrm{Cd}$ availability and, at the same time, $\mathrm{Cd}$ 477 toxicity. However, under control conditions, this modification induced already a decrease of 478 cell vitality. Indeed, in our previous work (Penen et al., 2017), C. reinhardtii grown in classic 479 TAP medium showed a higher growth rate $\left(1.15 \pm 0.03 \mathrm{~d}^{-1}\right)$ and a higher production of 480 chlorophyll $\left(10.78 \pm 0.38 \mu \mathrm{g} \mathrm{ml}^{-1} \mathrm{OD}_{\left.730 \mathrm{~nm}^{-1}\right)}\right.$ compared to the present study where microalgae

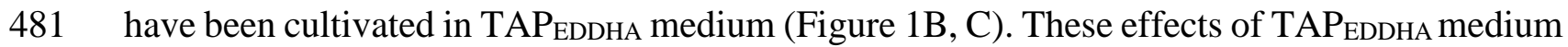
482 on cell vitality in control conditions could be explained by changes in the availability of some trace elements compared to the classic TAP medium (Table 1). Indeed, higher availability mainly of zinc but also, to a lesser extent, of copper, and in addition deficiency of cobalt was 485 found in the control TAP EDDHA medium.

\section{Cell response to cadmium stress}

487 Cell vitality results showed that a $70 \mu \mathrm{M} \mathrm{Cd}$ exposure for $48 \mathrm{~h}$ induced a decrease of the 488 chlorophyll concentration, which is a well-known sign of photosynthesis impairment (Nagel \& 489 Voigt, 1989; Collard \& Matagne, 1990; Nagel \& Voigt, 1995; Prasad, Drej, Skawińska \& 490 Strałka, 1998). The degradation of the chlorophyll pool was concomitant with a growth 491 decrease and an increase of carbon storage in the form of starch. Usually, this stress reaction

492 has been described in C. reinhardtii during nitrogen (Ball et al., 1990; Cakmak et al., 2012), 493 phosphorus (Ball et al., 1990) and sulfur (Ball et al., 1990; Cakmak et al., 2012) starvation. 
494 Moreover, Juergens et al. $(2015,2016)$ showed that starch was accumulated to maintain a 495 carbon pool during N-starvation instead of delaying photoinhibition and oxidative stress due 496 to energetic overflows from photosynthesis. In case of metallic stress, starch storage was 497 reported in Chlamydomonas acidophila (Nishikawa, Yamakoshi, Uemura \& Tominaga, 2003) 498 exposed to $20 \mu \mathrm{M}$ Cd where the size of starch plates observed microscopically increased 2.43-

499 fold. Metal stress could thus induce, in an indirect way, symptoms similar to those of nutrient starvation. Working with C. reinhardtii, Bräutigam et al. (2011) showed that Cd stress induced the synthesis of thiol polypeptides like phytochelatins, resulting in a decrease in the intracellular concentration of its precursors like glutathione, $\gamma$-EC and cysteine leading 503 presumably to a sulfur starvation. Although, sulfur supply by the medium should be sufficient 504 (Bräutigam et al., 2011), an intracellular sulfur deficiency is conceivable. Furthermore, a proteomic study (Gillet, Decottignies, Chardonnet \& Maréchal, 2006) revealed that enzymes involved in sulfur metabolism were modified under Cd stress in order to promote the synthesis

507 of phytochelatins.

\section{Cadmium is bound to RuBisCO in pyrenoid and to phosphate in acidocalcisome}

511 For the first time, a pyrenoidal sequestration of $\mathrm{Cd}$ and its binding to sulfur ligands were clearly

512 observed in C. reinhardtii. In addition, high sulfur and nitrogen content indicated a high protein

513 concentration in the pyrenoid. A model of the impact of $\mathrm{Cd}$ sequestration on carbon fixation in

514 C. reinhardtii is proposed in Figure 5. Pyrenoids are essentially composed of the protein

515 RuBisCO (Borkhsenious, Mason \& Moroney, 1998). They are the place of the carbon fixation

516 from $\mathrm{CO}_{2}$ via the Calvin cycle (Harris, 1989). Beside RuBisCO, the enzyme RuBisCO-activase

517 is involved in this process (McKay, Gibbs \& Vaughn, 1991). Thus, it can be hypothesized that 
$518 \mathrm{Cd}$ binding to protein thiol groups interferes with $\mathrm{CO}_{2}$ fixation in $C$. reinhardtii, for example

519 due to conformational changes caused by cadmium-thiol bonds. Indeed, it has been reported

520 that modifications at cysteines 449 and 459 of the RuBisCO large subunit induce a

521 conformational change and a decrease of its carboxylase activity (Marín-Navarro \& Moreno,

522 2006). Moreover, the RuBisCO large subunit protein is down-regulated under Cd exposure

523 (Gillet et al., 2006). For higher plants, it has been shown that $\mathrm{Cd}$ impairs the $\mathrm{CO}_{2}$ assimilation

524 rate by RuBisCO activity decrease, e.g. in the crop Lactuca sativa (Dias et al., 2012) and in

525 Nicotiana rustica (Afef, Leila, Donia, Houda \& Chiraz, 2011).

526 In addition, TEM/X-EDS, $\mu$ XRF and Cd L LII-edge XANES measurements have shown that $\mathrm{Cd}$

527 was also coordinated by phosphate ligands and localized in $0.5-1 \mu \mathrm{m}$ sized vacuoles containing

528 phosphorus and calcium. In our previous work (Penen et al., 2017), cadmium was shown to be

529 localized in vacuoles which were compared to acidocalcisomes due to their specific elemental

530 composition in phosphorus and calcium (Goodenough, Heiss, Roth, Rusch \& Lee, 2019; Hong-

531 Hermesdorf et al., 2014; Komine, Eggink, Park \& Hoober, 2000; Komine, Park, Wolfe \&

532 Hoober, 1996; Ruiz et al., 2001).

\section{$534 \mathrm{CO}_{2}$ fixation is impaired by cadmium stress}

535 Cadmium has been shown to disturb the light-dependent part of the photosynthesis (Faller et 536 al., 2005) but no study has previously focused on the impact of $\mathrm{Cd}$ on carbon assimilation. $C$.

537 reinhardtii is able to grow photoautotrophically using $\mathrm{CO}_{2}$, heterotrophically using acetate in 538 the dark and mixotrophically using both carbon sources in the light. In the present study, 539 mixotrophic growth conditions under constant illumination induced carbon storage as starch

540 (Figure 1D). Moreover, NanoSIMS analysis revealed that, carbon from acetate was 541 accumulated in the pyrenoid and in starch granules (Figure 4B). The pathways involved in 
acetate assimilation as well as the impact of cadmium on these pathways are discussed in the next paragraphs and are represented in Figure 5.

544 The accumulation of carbon from acetate in the pyrenoid can be explained by the assimilation

545 of acetate through the tricarboxylic acid cycle (TCA). Indeed, acetate assimilation starts with 546 its incorporation into acetyl coenzyme A (acetyl-CoA), either directly converted by acetyl-CoA 547 synthetase, or in two steps with the successive action of acetate kinase and phosphate 548 acetyltransferase. Acetyl-CoA is used as substrate in the TCA cycle in mitochondria. The TCA cycle produces ATP as well as NADH and releases the carbon of acetyl-CoA as $\mathrm{CO}_{2}$ (Johnson \& Alric, 2013). Then, the mitochondrial carbonic anhydrase CaH4/5 (Raven, 2001) converts $\mathrm{CO}_{2}$ in bicarbonate which is carried to the pyrenoid by the $\mathrm{CO}_{2}$ concentrating mechanism (CCM) (Meyer \& Griffiths, 2013). This latter is a combination of active carbon transporters

553 (Burow, Chen, Mouton \& Moroney, 1996; Im \& Grossman, 2002; Miura et al., 2004; Pollock, 554 Prout, Godfrey, Lemaire \& Moroney, 2004), carbonic anhydrases (Moroney et al., 2011) specific to cellular compartments and the soluble proteins (LCIB/LCIC) (Yamano et al., 2010) allowing $\mathrm{CO}_{2}$ trapping inside the pyrenoid. In the present work, the isotopic ratio of carbon

$557 \quad\left({ }^{13} \mathrm{C}\right.$ enrichment) inside the pyrenoid was similar under control and exposure conditions (Figure 558 4C) showing that cadmium did not seem to disturb TCA cycle and CCM.

559 Starch biosynthesis involves the successive actions of ADP-glucose pyrophosphorylase 560 (AGPP) and starch synthase (SS) on the final product of the gluconeogenesis pathway (glucose561 1-phosphate (G1P)). Carbon from acetate enters gluconeogenesis in two different ways, once 562 incorporated into AcetylCoA. On the one hand, as mentioned in the previous paragraph, 563 AcetylCoA feeds the TCA cycle releasing $\mathrm{CO}_{2}$. In the chloroplast, the two carbon sources thus 564 share the $\mathrm{CO}_{2}$ fixation step by $\mathrm{RuBisCO}$ into the Calvin cycle pathway. The final product of the Calvin cycle (glyceraldehyde-3-phosphate (G3P)) can enter the gluconeogenesis (Johnson 
566 \& Alric, 2013). On the other hand, Acetyl-CoA feeds the glyoxylate cycle which is a TCA

567 cycle where $\mathrm{CO}_{2}$ releasing steps are by-passed (Johnson \& Alric, 2012, 2013) in the cytosol.

568 Indeed, using AcetylCoA and isocitrate as substrates, isocitrate lyase produces glyoxylate and

569 succinate. This latter is successively converted in mitochondria to fumarate, malate,

570 oxaloacetate then phosphoenolpyruvate (PEP) which is exported to cytosol and enters the

571 gluconeogenesis pathway.

572 C. reinhardtii is able to assimilate inorganic carbon via PEP carboxylation by the two PEP 573 carboxylases $\mathrm{CrPpc} 1 / \mathrm{CrPpc} 2$, leading to the production of oxaloacetate (Mamedov, Moellering

\& Chollet, 2005). However, the algal PEP carboxylase activity is mainly anaplerotic and not

575 photosynthetic (Giordano, Norici, Forssen, Eriksson \& Raven, 2003). Although the impact of

576 cadmium on PEPC activity is not established in C. reinhardtii, it has been shown that Cd

577 inhibits PEPC activity in higher plants like Miscanthus species (Guo et al., 2016) and Zea mays

578 (Wang, Zhao, Liu, Zhou, \& Jin, 2009).

579 Despite ${ }^{13} \mathrm{C}$-[1,2] labeling of acetate, our experiments do not allow us to distinguish the

580 pathways taken by acetate carbons to be finally incorporated in starch. However, unlabeled

581 carbon assimilation from $\mathrm{CO}_{2}$ can only pass by the Calvin cycle. In consequence, after a $48 \mathrm{~h}$

582 Cd exposure, the relative decrease in ${ }^{12} \mathrm{C}$ from 73 to $39 \%$ of starch carbon (Figure 4D) shows

583 that carbon fixation through Calvin cycle pathway is limited by Cd stress but not completely

584 inhibited. Hence, the high increase of starch biosynthesis under Cd stress (Figure 1D) is

585 achieved in mixotrophic conditions by an about 4-fold higher carbon assimilation from acetate.

586 However, the overall amount of carbon assimilation from $\mathrm{CO}_{2}$ into starch remains limited in

587 relation to the increase of starch production (Figure 4E). Moreover, the decrease in chlorophyll

588 concentration (figure 1C) coupled with a massive accumulation of $\mathrm{Cd}$ in the pyrenoid (Figures 
2D, G and 3A) seems to disturb not only the light-dependent reactions (Faller et al., 2005) but also the light-independent reactions of photosynthesis. In unexposed C. reinhardtii grown under mixotrophic conditions, 78\% of total carbon (Heifetz et al., 2000) has been found to be from $\mathrm{CO}_{2}$ assimilation which is similar to the $73 \%$ of starch carbon originating from $\mathrm{CO}_{2}$ found in this work. Although $\mathrm{Cd}$ exposure and nutrient starvation have a similar impact on starch accumulation, the limitation of $\mathrm{CO}_{2}$ fixation is specific to $\mathrm{Cd}$ stress, since during nitrogen starvation, 65\% of starch carbon (Juergens et al., 2016) as well as $80 \%$ of total carbon (Juergens et al., 2016) are taken from an inorganic carbon source. In addition, enzymes involved in Calvin cycle have been shown to be down-regulated under $\mathrm{Cd}$ stress (phosphoglycerate kinase, ribose-5phosphate isomerase) while enzymes involved in acetate assimilation were up-regulated as for the isocitrate lyase (Gillet et al., 2006) involved

600 in the glyoxylate cycle or the phosphoglycerate mutase (Gillet et al., 2006) taking part in 601 gluconeogenesis.

602 Using NanoSIMS in combination with ${ }^{13} \mathrm{C}$-labeled acetate it was possible to detect, localize, 603 and quantify ${ }^{13} \mathrm{C}$-labeled starch as end product within the cells. Although these are important 604 results, the limitation of this approach is, that between the acetate substrate and the end product 605 no other metabolites of the carbon metabolism pathway during cadmium stress were measured.

606 A metabolomic or a fluxomic approach would be necessary to complete our results with regard 607 to the overall carbon fixation and metabolism pathway involved during cadmium stress in $C$. 608 reinhardtii.

609 In conclusion, the present work shows that cadmium clearly impairs carbon assimilation in $C$. 610 reinhardtii grown in mixotrophic conditions. Due to the pyrenoidal sequestration of $\mathrm{Cd}, \mathrm{CO}_{2}$ 611 fixation is limited during $\mathrm{Cd}$ exposure whereas acetate assimilation is favored. Mixotrophy 612 could thus allow phytoplankton surviving toxic metal pollution events. Although mixotrophy 
613 seems to render aquatic ecosystems more resistant, the alteration of $\mathrm{CO}_{2}$ fixation by toxic

614 metals could contribute to the unbalance of the biogeochemical carbon cycle.

\section{ACKNOWLEDGEMENTS}

616 The work was supported by funding from the French 'Ministère de l'Enseignement Supérieur

617 et de la Recherche' via the projects ANR-11-EQPX-0027 MARSS and ANR-10-INBS-04

618 FranceBioImaging, and a PhD fellowship for F.P. Furthermore, this work was supported by

619 the bilateral (German-French) DAAD - Campus France program PROCOPE funded by the

620 German 'Bundesministerium für Bildung und Forschung (BMBF)', the French 'Ministère des

621 Affaires étrangères et du développement International (MAEDI)' and 'Ministère de

622 l'Education nationale, de l'Enseignement supérieur et de la Recherche (MENESR)'. We also

623 thank ESRF (Grenoble, France) for the provision of beamtime on ID21 beamline. The

624 microscopy was done in the Bordeaux Imaging Center, a service unit of the CNRS-INSERM

625 and Bordeaux University, member of the national infrastructure France BioImaging. The

626 authors thank kindly Prof. U. Johanningmeier and Dr. I. Bertalan from the University Halle-

627 Wittenberg (Germany) for providing C. reinhardtii wild type strain (11/32b).

628 CONFLICT OF INTEREST

629 The authors declare no conflict of interests.

630

631

632 
634 Adams, M. S., Dillon, C. T., Vogt, S., Lai, B., Stauber, J., \& Jolley, D. F. (2016). Copper Uptake, Intracellular Localization, and Speciation in Marine Microalgae Measured by Synchrotron Radiation X-ray Fluorescence and Absorption Microspectroscopy. Environmental Science \& Technology, 50(16), 8827-8839.

Afef, N.-H., Leila, S., Donia, B., Houda, G., \& Chiraz, C.-H. (2011). Relationship between

Aguilera, A., \& Amils, R. (2005). Tolerance to cadmium in Chlamydomonas sp. (Chlorophyta) strains isolated from an extreme acidic environment, the Tinto River (SW, Spain). Aquatic Toxicology, 75(4), 316-329.

Aksmann, A., Pokora, W., Baścik-Remisiewicz, A., Dettlaff-Pokora, A., Wielgomas, B., Dziadziuszko, M., \& Tukaj, Z. (2014). Time-dependent changes in antioxidative enzyme expression and photosynthetic activity of Chlamydomonas reinhardtii cells under acute exposure to cadmium and anthracene. Ecotoxicology and Environmental Safety, 110, 31-40.

Arnon, D. I. (1949). Copper Enzymes in Isolated Chloroplasts. Polyphenoloxidase in Beta Vulgaris. Plant Physiology, 24(1), 1-15.

Badger, M. R., Andrews, T. J., Whitney, S. M., Ludwig, M., Yellowlees, D. C., Leggat, W., \& Price, G. D. (1998). The diversity and coevolution of Rubisco, plastids, pyrenoids, and chloroplast-based CO2-concentrating mechanisms in algae. Canadian Journal of Botany, 76(6), 1052-1071.

Ball, S. G., Dirick, L., Decq, A., Martiat, J.-C., \& Matagne, R. (1990). Physiology of starch storage in the monocellular alga Chlamydomonas reinhardtii. Plant Science, 66(1), 19. 
658 Borkhsenious, O. N., Mason, C. B., \& Moroney, J. V. (1998). The Intracellular Localization

659

660

661

662

663

664

665

666

667

668

669

670

671

672

673

674

675

676

677

678

679

680

of Ribulose-1,5-Bisphosphate Carboxylase/Oxygenase in Chlamydomonas reinhardtii. Plant Physiology, 116(4), 1585-1591.

Bräutigam, A., Schaumlöffel, D., Krauss, G.-J., \& Wesenberg, D. (2009). Analytical approach for characterization of cadmium-induced thiol peptides - a case study using Chlamydomonas reinhardtii. Analytical and Bioanalytical Chemistry, 395(6), 17371747.

Bräutigam, A., Schaumlöffel, D., Preud'Homme, H., Thondorf, I., \& Wesenberg, D. (2011). Physiological characterization of cadmium-exposed Chlamydomonas reinhardtii. Plant, Cell and Environment, 34(12), 2071-2082.

Burkholder, J. M., Glibert, P. M., \& Skelton, H. M. (2008). Mixotrophy, a major mode of nutrition for harmful algal species in eutrophic waters. Harmful Algae, 8(1), 77-93.

Burow, M. D., Chen, Z.-Y., Mouton, T. M., \& Moroney, J. V. (1996). Isolation of cDNA clones of genes induced upon transfer of Chlamydomonas reinhardtii cells to low $\mathrm{CO} 2$. Plant Molecular Biology, 31(2), 443-448.

Cakmak, T., Angun, P., Demiray, Y. E., Ozkan, A. D., Elibol, Z., \& Tekinay, T. (2012). Differential effects of nitrogen and sulfur deprivation on growth and biodiesel feedstock production of Chlamydomonas reinhardtii. Biotechnology and Bioengineering, 109(8), $1947-1957$.

Campbell, P. G. C. (2006). Cadmium-A priority pollutant. Environmental Chemistry, 3(6), $387-388$.

Caron, D. A. (2016). Mixotrophy stirs up our understanding of marine food webs. Proceedings of the National Academy of Sciences, 113(11), 2806-2808. 
681 Clode, P. L., Stern, R. A., \& Marshall, A. T. (2007). Subcellular imaging of isotopically labeled 682 carbon compounds in a biological sample by ion microprobe (NanoSIMS). Microscopy Research and Technique, 70(3), 220-229.

Collard, J. M., \& Matagne, R. F. (1990). Isolation and genetic analysis of Chlamydomonas reinhardtii strains resistant to cadmium. Applied and Environmental Microbiology, 56(7), 2051-2055.

687

Cotte, M., Pouyet, E., Salomé, M., Rivard, C., Nolf, W. D., Castillo-Michel, H., Fabris, T., 688 Monico, L., Janssens, K., Wang, T., Sciau, P., Verger, L., Cormier, L., Dargaud, O., Brun, E., Bugnazet, D., Fayard, B., Hesse, B., Real, A.E.P., Veronesi, G., Langlois, J., Balcar, N., Vandenberghe, Y., Solé, V.A., Kieffer, J., Barrett, R., Cohen, C., Cornu, C., Baker, R., Gagliardini, E., Papillon, E. \& Susini, J. (2017). The ID21 X-ray and infrared

Croteau, M.-N., Luoma, S. N., \& Stewart, A. R. (2005). Trophic transfer of metals along freshwater food webs: Evidence of cadmium biomagnification in nature. Limnology and Oceanography, 50(5), 1511-1519.

Delrue, B., Fontaine, T., Routier, F., Decq, A., Wieruszeski, J. M., Van Den Koornhuyse, N., 698 Maddelein, M.L., Fournet, B. \& Ball, S. (1992). Waxy Chlamydomonas reinhardtii: monocellular algal mutants defective in amylose biosynthesis and granule-bound starch synthase activity accumulate a structurally modified amylopectin. Journal of Bacteriology, 174(11), 3612-3620.

Dent, R. M., Han, M., \& Niyogi, K. K. (2001). Functional genomics of plant photosynthesis in the fast lane using Chlamydomonas reinhardtii. Trends in Plant Science, 6(8), 364-371. 
Dias, M. C., Monteiro, C., Moutinho-Pereira, J., Correia, C., Gonçalves, B., \& Santos, C. (2012). Cadmium toxicity affects photosynthesis and plant growth at different levels. Acta Physiologiae Plantarum, 35(4), 1281-1289.

Ellis, R. J. (1979). The most abundant protein in the world. Trends in Biochemical Sciences, 4(11), 241-244.

Faller, P., Kienzler, K., \& Krieger-Liszkay, A. (2005). Mechanism of Cd2+ toxicity: Cd2+ inhibits photoactivation of Photosystem II by competitive binding to the essential Ca2+ site. Biochimica et Biophysica Acta (BBA) - Bioenergetics, 1706(1-2), 158-164.

Field, C. B., Behrenfeld, M. J., Randerson, J. T., \& Falkowski, P. (1998). Primary Production of the Biosphere: Integrating Terrestrial and Oceanic Components. Science, 281(5374), $237-240$

Gao, D., Huang, X., \& Tao, Y. (2016). A critical review of NanoSIMS in analysis of microbial metabolic activities at single-cell level. Critical Reviews in Biotechnology, 36(5), 884890.

Gekeler, W., Grill, E., Winnacker, E.-L., \& Zenk, M. H. (1988). Algae sequester heavy metals via synthesis of phytochelatin complexes. Archives of Microbiology, 150(2), 197-202.

Gillet, S., Decottignies, P., Chardonnet, S., \& Maréchal, P. L. (2006). Cadmium response and redoxin targets in Chlamydomonas reinhardtii: a proteomic approach. Photosynthesis Research, 89(2-3), 201-211.

Giordano, M., Norici, A., Forssen, M., Eriksson, M., \& Raven, J. A. (2003). An Anaplerotic Role for Mitochondrial Carbonic Anhydrase in Chlamydomonas reinhardtii. Plant Physiology, 132(4), 2126-2134.

Goodenough, U., Heiss, A. A., Roth, R., Rusch, J., \& Lee, J.-H. (2019). Acidocalcisomes: Ultrastructure, Biogenesis, and Distribution in Microbial Eukaryotes. Protist, 170(3), $287-313$. 
729 Goodenough, U. W., Shames, B., Small, L., Saito, T., Crain, R. C., Sanders, M. A., \& Salisbury, J. L. (1993). The role of calcium in the Chlamydomonas reinhardtii mating reaction. Journal of Cell Biology, 121(2), 365-374.

Goto, K., \& Johnson, C. H. (1995). Is the cell division cycle gated by a circadian clock? The case of Chlamydomonas reinhardtii. The Journal of Cell Biology, 129(4), 1061-1069.

Guo, H., Hong, C., Chen, X., Xu, Y., Liu, Y., Jiang, D., \& Zheng, B. (2016). Different Growth and Physiological Responses to Cadmium of the Three Miscanthus Species. PLOS ONE, 11(4), e0153475.

Gustafsson, J., Petter. (2013). Visual MINTEQ | Visual MINTEQ - a free equilibrium speciation model. Retrieved March 31, 2017, from http://vminteq.lwr.kth.se/.

Hanikenne, M. (2003). Chlamydomonas reinhardtii as a eukaryotic photosynthetic model for studies of heavy metal homeostasis and tolerance. New Phytologist, 159(2), 331-340.

Harris, E. H. (1989). The Chlamydomonas Sourcebook: Introduction to Chlamydomonas and Its Laboratory Use. Academic Press, Inc. San Diego.

Hartmann, M., Grob, C., Tarran, G. A., Martin, A. P., Burkill, P. H., Scanlan, D. J., \& Zubkov, M. V. (2012). Mixotrophic basis of Atlantic oligotrophic ecosystems. Proceedings of the National Academy of Sciences, 109(15), 5756-5760.

Heifetz, P. B., Förster, B., Osmond, C. B., Giles, L. J., \& Boynton, J. E. (2000). Effects of Acetate on Facultative Autotrophy inChlamydomonas reinhardtii Assessed by

Hong-Hermesdorf, A., Miethke, M., Gallaher, S. D., Kropat, J., Dodani, S. C., Chan, J., 
identifies dynamic sites of $\mathrm{Cu}$ accumulation in Chlamydomonas. Nature Chemical Biology, 10(12): 1034-1042.

755

756

757

758

759

760

761

762

763

764

765

766

767

768

769

770

771

772

773

774

775

Hoppe, P., Cohen, S., \& Meibom, A. (2013). NanoSIMS: Technical Aspects and Applications in Cosmochemistry and Biological Geochemistry. Geostandards and Geoanalytical Research, 37(2), 111-154.

Huguet, S., Bert, V., Laboudigue, A., Barthès, V., Isaure, M.-P., Llorens, I., Schat, H. \& Sarret, G. (2012). Cd speciation and localization in the hyperaccumulator Arabidopsis halleri. Environmental and Experimental Botany, 82, 54-65.

Ikemoto, T., Tu, N. P. C., Okuda, N., Iwata, A., Omori, K., Tanabe, S., Tuyen, B.C. \& Takeuchi, I. (2008). Biomagnification of Trace Elements in the Aquatic Food Web in the Mekong Delta, South Vietnam Using Stable Carbon and Nitrogen Isotope Analysis. Archives of Environmental Contamination and Toxicology, 54(3), 504-515.

Im, C. S., \& Grossman, A. R. (2002). Identification and regulation of high light-induced genes in Chlamydomonas reinhardtii. The Plant Journal, 30(3), 301-313.

Isaure, M.-P., Fayard, B., Sarret, G., Pairis, S., \& Bourguignon, J. (2006). Localization and chemical forms of cadmium in plant samples by combining analytical electron microscopy and X-ray spectromicroscopy. Spectrochimica Acta Part B: Atomic Spectroscopy, 61(12), 1242-1252.

Isaure, M.-P., Huguet, S., Meyer, C.-L., Castillo-Michel, H., Testemale, D., Vantelon, D., Saumitou-Laprade, P., Verbruggen, N. \& Sarret, G. (2015). Evidence of various mechanisms of $\mathrm{Cd}$ sequestration in the hyperaccumulator Arabidopsis halleri, the nonaccumulator Arabidopsis lyrata, and their progenies by combined synchrotron-based techniques. Journal of Experimental Botany, 66(11), 3201-3214. 
Johnson, X., \& Alric, J. (2012). Interaction between Starch Breakdown, Acetate Assimilation, and Photosynthetic Cyclic Electron Flow in Chlamydomonas reinhardtii. Journal of Biological Chemistry, 287(31), 26445-26452.

Johnson, X., \& Alric, J. (2013). Central Carbon Metabolism and Electron Transport in Chlamydomonas reinhardtii: Metabolic Constraints for Carbon Partitioning between Oil and Starch. Eukaryotic Cell, 12(6), 776-793.

Juergens, M. T., Deshpande, R. R., Lucker, B. F., Park, J.-J., Wang, H., Gargouri, M., Holguin, F.O., Disbrow, B., Schaub, T., Skepper, J.N., Kramer, D.M., Gang, D.R., Hicks, L.M. \& Shachar-Hill, Y. (2015). The Regulation of Photosynthetic Structure and Function during Nitrogen Deprivation in Chlamydomonas reinhardtii. Plant Physiology, 167(2), $558-573$.

Juergens, M. T., Disbrow, B., \& Shachar-Hill, Y. (2016). The Relationship of Triacylglycerol and Starch Accumulation to Carbon and Energy Flows during Nutrient Deprivation in Chlamydomonas reinhardtii. Plant Physiology, 171(4), 2445-2457.

Komine, Y., Eggink, L. L., Park, H., \& Hoober, J. K. (2000). Vacuolar granules in Chlamydomonas reinhardtii: polyphosphate and a 70-kDa polypeptide as major components. Planta, 210(6), 897-905.

Komine, Y., Park, H., Wolfe, G. R., \& Hoober, J. K. (1996). Secretory granules in the cytoplasm of a wall-less mutant of Chlamydomonas reinhardtii contain processed lightharvesting complex apoproteins and HSP70. Journal of Photochemistry and Photobiology B: Biology, 36(3), 301-306.

Kopp, C., Domart-Coulon, I., Escrig, S., Humbel, B. M., Hignette, M., \& Meibom, A. (2015). Subcellular Investigation of Photosynthesis-Driven Carbon Assimilation in the Symbiotic Reef Coral Pocillopora damicornis. mBio, 6(1), e02299-14. 
800 Lavoie, M., Fortin, C., \& Campbell, P. G. C. (2012). Influence of essential elements on cadmium uptake and toxicity in a unicellular green alga: The protective effect of trace zinc and cobalt concentrations. Environmental Toxicology and Chemistry, 31(7), 14451452.

Lechene, C., Hillion, F., McMahon, G., Benson, D., Kleinfeld, A. M., Kampf, J. P., Distel, D., Luyten, Y., Bonventre, J., Hentschel, D., Park, K.M., Ito, S., Schwartz, M., Benichou, G. \& Slodzian, G. (2006). High-resolution quantitative imaging of mammalian and bacterial cells using stable isotope mass spectrometry. Journal of Biology, 5, 20.

Lee, T.-M., Lai, H.-Y., \& Chen, Z.-S. (2004). Effect of chemical amendments on the concentration of cadmium and lead in long-term contaminated soils. Chemosphere, 57(10), 1459-1471.

Leonardo, T., Farhi, E., Boisson, A.-M., Vial, J., Cloetens, P., Bohic, S., \& Rivasseau, C. (2014). Determination of elemental distribution in green micro-algae using synchrotron radiation nano X-ray fluorescence (SR-nXRF) and electron microscopy techniques -

Leonardo, T., Farhi, E., Pouget, S., Motellier, S., Boisson, A.-M., Banerjee, D., Rébeillé, F., den Auwer, C. \& Rivasseau, C. (2016). Silver Accumulation in the Green Microalga Coccomyxa actinabiotis: Toxicity, in Situ Speciation, and Localization Investigated Using Synchrotron XAS, XRD, and TEM. Environmental Science \& Technology, 50(1), 359-367.

Lindsay, W. L. (1979). Chemical equilibria in soils. John Wiley \& Sons, New York. copper, and nickel on growth of the green alga Chlamydomonas reinhardtii: The 

Toxicology, 27(4), 454-458.

826

827

828

829

830

831

832

833

834

835

836

837

838

839

840

841

842

843

844

845

846

847

848

Mackinder, L. C. M., Meyer, M. T., Mettler-Altmann, T., Chen, V. K., Mitchell, M. C., Caspari, O., Rosenzweig, E.S.F., Pallesen, L., Reeves, G., Itakura, A., Roth, R., Sommer, F., Geimer, S., Mühlhaus, T., Schroda, M., Goodenough, U., Stitt, M., Griffiths, H. \& Jonikas, M. C. (2016). A repeat protein links Rubisco to form the eukaryotic carbon-concentrating organelle. Proceedings of the National Academy of Sciences, 113(21), 5958-5963.

Malherbe, J., Penen, F., Isaure, M.-P., Frank, J., Hause, G., Dobritzsch, D., Gontier, E., Horréard, F., Hillion, F. \& Schaumlöffel, D. (2016). A New Radio Frequency Plasma Oxygen Primary Ion Source on Nano Secondary Ion Mass Spectrometry for Improved Lateral Resolution and Detection of Electropositive Elements at Single Cell Level. Analytical Chemistry, 88(14), 7130-7136.

Mamedov, T. G., Moellering, E. R., \& Chollet, R. (2005). Identification and expression analysis of two inorganic C- and N-responsive genes encoding novel and distinct molecular forms of eukaryotic phosphoenolpyruvate carboxylase in the green microalga Chlamydomonas reinhardtii. The Plant Journal, 42(6), 832-843.

Marín-Navarro, J., \& Moreno, J. (2006). Cysteines 449 and 459 modulate the reductionoxidation conformational changes of ribulose $1 \cdot 5$-bisphosphate carboxylase/oxygenase and the translocation of the enzyme to membranes during stress. Plant, Cell \& Environment, 29(5), 898-908.

McKay, R. M. ., Gibbs, S. P., \& Vaughn, K. C. (1991). RuBisCo activase is present in the pyrenoid of green algae. Protoplasma, (162), 38-45.

Merchant, S. S., Allen, M. D., Kropat, J., Moseley, J. L., Long, J. C., Tottey, S., \& Terauchi, A. M. (2006). Between a rock and a hard place: Trace element nutrition in 

1763(7), 578-594.

Merchant, S. S., Kropat, J., Liu, B., Shaw, J., \& Warakanont, J. (2012). TAG, You're it! Chlamydomonas as a reference organism for understanding algal triacylglycerol accumulation. Current Opinion in Biotechnology, 23(3), 352-363.

Merchant, S. S., Prochnik, S. E., Vallon, O., Harris, E. H., Karpowicz, S. J., Witman, G. B., ... Grossman, A. R. (2007). The Chlamydomonas Genome Reveals the Evolution of Key Animal and Plant Functions. Science, 318(5848), 245-250.

Meyer, M., \& Griffiths, H. (2013). Origins and diversity of eukaryotic CO2-concentrating mechanisms: lessons for the future. Journal of Experimental Botany, 64(3), 769-786.

Miura, K., Yamano, T., Yoshioka, S., Kohinata, T., Inoue, Y., Taniguchi, F., Asamizu, E., Nakamura, Y., Tabata, S., Yamato, K.T., Ohyama, K. \& Fukuzawa, H. (2004). Expression Profiling-Based Identification of CO2-Responsive Genes Regulated by CCM1 Controlling a Carbon-Concentrating Mechanism in Chlamydomonas reinhardtii. Plant Physiology, 135(3), 1595-1607.

Moore, K. L., Schröder, M., Lombi, E., Zhao, F.-J., McGrath, S. P., Hawkesford, M. J., 865 Shewry, P.R. \& Grovenor, C. R. M. (2010). NanoSIMS analysis of arsenic and selenium in cereal grain. New Phytologist, 185(2), 434-445.

Moore, K. L., Schröder, M., Wu, Z., Martin, B. G. H., Hawes, C. R., McGrath, S. P., Hawkesford, M.J., Ma, J.F., Zhao, F.-J. \& Grovenor, C. R. M. (2011). High-Resolution Secondary Ion Mass Spectrometry Reveals the Contrasting Subcellular Distribution of Arsenic and Silicon in Rice Roots. Plant Physiology, 156(2), 913-924. Hawkesford, M.J., McGrath, S.P., Shewry, P.R. \& Grovenor, C. R. M. (2012). 
873

874

875

876

877

878

879

880

881

882

883

884

885

886

887

888

889

890

891

892

893

894

895

896

897

Localisation of iron in wheat grain using high resolution secondary ion mass spectrometry. Journal of Cereal Science, 55(2), 183-187.

Moroney, J. V., Ma, Y., Frey, W. D., Fusilier, K. A., Pham, T. T., Simms, T. A., DiMario, R.J., Yang, J. \& Mukherjee, B. (2011). The carbonic anhydrase isoforms of Chlamydomonas reinhardtii: intracellular location, expression, and physiological roles. Photosynthesis Research, 109(1-3), 133-149.

Nagel, K., \& Voigt, J. (1989). In Vitro Evolution and Preliminary Characterization of a Cadmium-Resistant Population of Chlamydomonas reinhardtii. Applied and Environmental Microbiology, 55(2), 526-528.

Nagel, K., \& Voigt, J. (1995). Impaired photosynthesis in a cadmium-tolerant Chlamydomonas mutant strain. Microbiological Research, 150(1), 105-110.

Nishikawa, K., Yamakoshi, Y., Uemura, I., \& Tominaga, N. (2003). Ultrastructural changes in Chlamydomonas acidophila (Chlorophyta) induced by heavy metals and polyphosphate metabolism. FEMS Microbiology Ecology, 44(2), 253-259.

Ortega, R., Devès, G., \& Carmona, A. (2009). Bio-metals imaging and speciation in cells using proton and synchrotron radiation X-ray microspectroscopy. Journal of The Royal Society Interface, 6(Suppl 5), S649-S658.

O’Toole, E. T. (2010). Chlamydomonas. Cryopreparation methods for the 3-D analysis of cellular organelles. Methods Cellular Biology, 96, 71-91.

Park, J.-J., Wang, H., Gargouri, M., Deshpande, R. R., Skepper, J. N., Holguin, F. O., Juergens, M.T., Shachar-Hill, Y., Hicks, L.M. \& Gang, D. R. (2015). The response of Chlamydomonas reinhardtii to nitrogen deprivation: a systems biology analysis. The Plant Journal, 81(4), 611-624.

Penen, F., Isaure, M. P., Dobritzsch, D., Bertalan, I., Castillo-Michel, H., Proux, O., Gontier, E., Le Coustumer, P. \& Schaumlöffel, D. (2017). Pools of cadmium in Chlamydomonas 
reinhardtii revealed by chemical imaging and XAS spectroscopy. Metallomics,9, 910923.

Penen, F., Malherbe, J., Isaure, M.-P., Dobritzsch, D., Bertalan, I., Gontier, E., Le Coustumer, P. \& Schaumlöffel, D. (2016). Chemical bioimaging for the subcellular localization of trace elements by high contrast TEM, TEM/X-EDS, and NanoSIMS. Journal of Trace Elements in Medicine and Biology, 37, 62-68.

905

Pollock, S. V., Prout, D. L., Godfrey, A. C., Lemaire, S. D., \& Moroney, J. V. (2004). The Chlamydomonas reinhardtii proteins Ccp1 and Ccp2 are required for long-term growth, but are not necessary for efficient photosynthesis, in a low-CO2 environment. Plant Molecular Biology, 56(1), 125-132.

908

909

910

911

912

913

914

915

916

917

918

919

920

921

Prasad, M. N. V., Drej, K., Skawińska, A., \& Strałka, K. (1998). Toxicity of Cadmium and Copper in Chlamydomonas reinhardtii Wild-Type (WT 2137) and Cell Wall Deficient Mutant Strain (CW 15). Bulletin of Environmental Contamination and Toxicology, 60(2), 306-311.

Ramani, S., Dragun, Z., Kapetanović, D., Kostov, V., Jordanova, M., Erk, M., \& HajrulaiMusliu, Z. (2014). Surface Water Characterization of Three Rivers in the Lead/Zinc Mining Region of Northeastern Macedonia. Archives of Environmental Contamination and Toxicology, 66(4), 514-528.

Ravel, B., \& Newville, M. (2005). ATHENA , ARTEMIS , HEPHAESTUS : data analysis for X-ray absorption spectroscopy using IFEFFIT. Journal of Synchrotron Radiation, 12(4), 537-541.

Raven, J. A. (2001). A role for mitochondrial carbonic anhydrase in limiting CO2 leakage from low CO2-grown cells of Chlamydomonas reinhardtii. Plant, Cell \& Environment, 24(2), 261-265. 
Rochaix, J.-D., M. Goldschmidt-Clermont \& Merchant, S. (1998). The Molecular Biology of Chloroplasts and Mitochondria in Chlamydomonas. Kluwer Academic Publishers, Dordrecht, The Netherlands.

Roschzttardtz, H., Grillet, L., Isaure, M.-P., Conéjéro, G., Ortega, R., Curie, C., \& Mari, S. (2011). Plant Cell Nucleolus as a Hot Spot for Iron. Journal of Biological Chemistry, 286(32), 27863-27866.

Rouleau, C., Gobeil, C., \& Tjlve, H. (2006). Cadmium accumulation in coastal demersal fish. Marine Ecology Progress Series, 311, 131-143.

Ruiz, F. A., Marchesini, N., Seufferheld, M., Govindjee, \& Docampo, R. (2001). The Polyphosphate Bodies of Chlamydomonas reinhardtii Possess a Proton-pumping Pyrophosphatase and Are Similar to Acidocalcisomes. Journal of Biological Chemistry, 276(49), 46196-46203.

Sarret, G., Smits, E. A. H. P., Michel, H. C., Isaure, M. P., Zhao, F. J. \& Tappero, R. (2013). Chapter One - Use of Synchrotron-Based Techniques to Elucidate Metal Uptake and Metabolism in Plants. In D. L. Sparks (Ed.), Advances in Agronomy (pp. 1-82).

Schaumlöffel, D., Hutchinson, R., Malherbe, J., Le Coustumer, P., Gontier, E. \& Isaure, M.-P. (2016), Novel Methods for Bioimaging Including LA-ICP-MS, NanoSIMS, TEM/XEDS, and SXRF, In: Metallomics: Analytical Techniques and Speciation Methods,ed. Michalke, B., John Wiley and Sons, ISBN 978-3-527-33969-3, Wiley-VCH Verlag GmbH, Weinheim, pp. 83-116

Signa, G., Mazzola, A., Tramati, C. D., \& Vizzini, S. (2017). Diet and habitat use influence Hg and $\mathrm{Cd}$ transfer to fish and consequent biomagnification in a highly contaminated area: Augusta Bay (Mediterranean Sea). Environmental Pollution, 230, 394-404. 
945 Silflow, C. D., \& Lefebvre, P. A. (2001). Assembly and Motility of Eukaryotic Cilia and Flagella. Lessons from Chlamydomonas reinhardtii. Plant Physiology, 127(4), 1500-

947 1507.

Simmons, R. W., Pongsakul, P., Saiyasitpanich, D., \& Klinphoklap, S. (2005). Elevated levels of cadmium and zinc in paddy soils and elevated levels of cadmium in rice grain downstream of a zinc mineralized area in Thailand: implications for public health. Environmental Geochemistry and Health, 27(5-6), 501-511.

952

Singh, H., Shukla, M. R., Chary, K. V. R., \& Rao, B. J. (2014). Acetate and Bicarbonate Assimilation and Metabolite Formation in Chlamydomonas reinhardtii: A 13C-NMR Study. PLOS ONE, 9(9), e106457.

955

Solé, V. A., Papillon, E., Cotte, M., Walter, P., \& Susini, J. (2007). A multiplatform code for 956 the analysis of energy-dispersive X-ray fluorescence spectra. Spectrochimica Acta Part 957 B: Atomic Spectroscopy, 62(1), 63-68.

Stoiber, T. L., Shafer, M. M., \& Armstrong, D. E. (2012). Relationships between surface-bound 959 and internalized copper and cadmium and toxicity in Chlamydomonas reinhardtii. Environmental Toxicology and Chemistry, 31(2), 324-335.

Terrado, R., Pasulka, A. L., Lie, A. A.-Y., Orphan, V. J., Heidelberg, K. B., \& Caron, D. A. 962 (2017). Autotrophic and heterotrophic acquisition of carbon and nitrogen by a mixotrophic chrysophyte established through stable isotope analysis. The ISME Journal, 11(9), 2022-2034.

Vega, J. M., Garbayo, I., Domínguez, M. J., \& Vigara, J. (2006). Effect of abiotic stress on 966 photosynthesis and respiration in Chlamydomonas reinhardtii: Induction of oxidative stress. Enzyme and Microbial Technology, 40(1), 163-167. 
Voigt, J., \& Nagel, K. (2002). The donor side of photosystem II is impaired in a Cd2+-tolerant mutant strain of the unicellular green algaChlamydomonas reinhardtii. Journal of Plant Physiology, 159(9), 941-950.

Voigt, J., Nagel, K., \& Wrann, D. (1998). A Cadmium-tolerant Chlamydomonas Mutant Strain Impaired in Photosystem II Activity. Journal of Plant Physiology, 153(5-6), 566-573.

Wang, H., Zhao, S. C., Liu, R. L., Zhou, W., \& Jin, J. Y. (2009). Changes of photosynthetic activities of maize (Zea mays L.) seedlings in response to cadmium stress. Photosynthetica, 47(2), 277-283.

Wang, S., Lv, J., Ma, J., \& Zhang, S. (2016). Cellular internalization and intracellular biotransformation of silver nanoparticles in Chlamydomonas reinhardtii. Nanotoxicology, 10(8), 1129-1135.

Ward, B. A., \& Follows, M. J. (2016). Marine mixotrophy increases trophic transfer efficiency, mean organism size, and vertical carbon flux. Proceedings of the National Academy of Sciences, 113(11), 2958-2963.

Worden, A. Z., Follows, M. J., Giovannoni, S. J., Wilken, S., Zimmerman, A. E., \& Keeling, P. J. (2015). Rethinking the marine carbon cycle: Factoring in the multifarious lifestyles of microbes. Science, 347(6223), 1257594.

Xue, H., \& Sigg, L. (1998). Cadmium speciation and complexation by natural organic ligands in fresh water. Analytica Chimica Acta, 363(2-3), 249-259.

Yamano, T., Tsujikawa, T., Hatano, K., Ozawa, S.-I., Takahashi, Y., \& Fukuzawa, H. (2010). Light and low-CO2-dependent LCIB-LCIC complex localization in the chloroplast supports the carbon-concentrating mechanism in Chlamydomonas reinhardtii. Plant \& Cell Physiology, 51(9), 1453-1468. 
995 Table 1: Comparison of ion availability in classic TAP medium and TAPEDDHA medium.

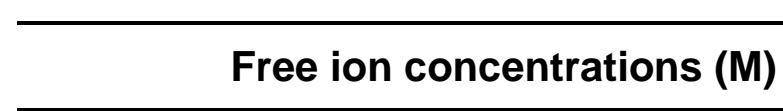

\begin{tabular}{ccccc} 
& \multicolumn{2}{c}{ TAP } & \multicolumn{2}{c}{ TAPEDDHA } \\
\cline { 2 - 5 } Metal ions & Control & $70 \mu \mathrm{M} \mathrm{Cd}$ & Control & $70 \mu \mathrm{M} \mathrm{Cd}$ \\
\hline $\mathrm{Ca}^{2+}$ & $2.510^{-5}$ & $2.610^{-5}$ & $2.610^{-5}$ & $2.610^{-5}$ \\
$\mathrm{Mg}^{2+}$ & $3.110^{-4}$ & $3.110^{-4}$ & $3.110^{-4}$ & $3.110^{-4}$ \\
$\mathrm{Fe}^{2+}$ & $5.610^{-9}$ & $5.010^{-7}$ & - & - \\
$\mathrm{Fe}^{3+}$ & - & - & $1.110^{-22}$ & $1.210^{-22}$ \\
$\mathrm{Zn}^{2+}$ & $2.410^{-10}$ & $3.010^{-6}$ & $3.110^{-6}$ & $3.110^{-6}$ \\
$\mathrm{Cu}^{2+}$ & $6.510^{-14}$ & $6.110^{-10}$ & $6.910^{-12}$ & $7.510^{-12}$ \\
$\mathrm{Co}^{2+}$ & $1.510^{-11}$ & $2.010^{-7}$ & $5.610^{-15}$ & $4.710^{-15}$ \\
$\mathrm{Mn}^{2+}$ & $10.710^{-10}$ & $8.010^{-10}$ & $8.310^{-10}$ & $8.410^{-10}$ \\
$\mathrm{MoO}_{4}{ }^{2-}$ & $5.610^{-6}$ & $1.110^{-8}$ & $5.610^{-6}$ & $1.110^{-9}$ \\
$\mathrm{Cd}^{2+}$ & - & $2.110^{-6}$ & - & $2.010^{-5}$ \\
\hline
\end{tabular}

996

997

998

999

1000 FIGURE CAPTIONS

1001 Figure 1: Impact of cadmium exposure to C. reinardtii grown in TAPEDDHA medium. (A)

1002 Relative growth rate was expressed as the ratio $\mu / \mu 0$ determined during the exponential phase 
1003 of growth after addition of $0,10,20,30,40,50$ and $70 \mu \mathrm{M}$ of $\mathrm{CdCl}_{2} .(\mathrm{n}=3 \pm \mathrm{sd}) . \mu=$ growth

1004 rate during cadmium exposure, $\mu_{\mathrm{O}}=$ growth rate in control conditions. Black curve represents

1005 the dose-response effect calculated with the Hill model. Impact of a $70 \mu \mathrm{M} \mathrm{Cd}$ exposure on

1006 growth (B) and on chlorophyll concentration (C), and starch concentration (D) after a $48 \mathrm{~h}$

1007 exposure. Significant differences with respect to the control condition at a significance level of

$10080.05(\mathrm{p}<0.05)$ are indicated by an asterisk $(*)$.

1009 Figure 2: Structure and elemental composition of $C$. reinhardtii cells exposed to cadmium. (A)

1010 Electron micrographs of two C. reinhardtii cells in control condition and (B) of two cells

1011 exposed to $70 \mu \mathrm{M}$ Cd for $48 \mathrm{~h}$, scale bar $=1 \mu \mathrm{m}$. Abbreviations: N, nucleus; P, pyrenoid; $\mathrm{S}$,

1012 starch; Th, thylakoid; CW, cell wall. (C to $\mathrm{H}$ ) Correlative TEM/X-EDS and NanoSIMS

1013 imaging of two cadmium exposed $C$. reinhardtii cells: (C and F) Electron micrographs of $C$.

1014 reinhardtii cells exposed to $70 \mu \mathrm{M}$ Cd for $48 \mathrm{~h}$, white arrows show the area analyzed by X-

1015 EDS analysis, scale bar $=1 \mu \mathrm{m}$. Abbreviations: N, nucleus; P, pyrenoid; S, starch; Th,

1016 thylakoid; V, vacuole; CV, contractile vacuole; CW, cellwall. (E and H) Corresponding

1017 NanoSIMS elemental maps obtained by $\mathrm{Cs}^{+}$ion source $\left({ }^{12} \mathrm{C}^{14} \mathrm{~N}^{-}\right.$for $\mathrm{N}$ detection, $\left.{ }^{32} \mathrm{~S}^{-}\right)$and $\mathrm{O}^{-}$

1018 RF plasma ion source $\left({ }^{31} \mathrm{P}^{+},{ }^{40} \mathrm{Ca}^{+}\right), 10 \times 10 \mu \mathrm{m}^{2}$ (E) and $12 \times 12 \mu \mathrm{m}^{2}$ (H) fields of $256 \times 256$

1019 pixels, scale bar $=2 \mu \mathrm{m}$. (D and G) X-EDS spectra of vacuoles and pyrenoid located on electron

1020 micrographs, copper signal is produced by the copper grid

1021 Figure 3: In situ cadmium localization and speciation in C. reinhardtii exposed to $70 \mu \mathrm{M} \mathrm{Cd}$ 1022 for 48 in TAPEDDHA medium. (A) False color $\mu$-XRF elemental maps of Cd, S, P and Ca, arrows 1023 show points of interest where $\mu$-XANES analyses were performed, scale bar $=2 \mu \mathrm{m}$. Step size $1024=0.4 \mu \mathrm{m}$, dwell-time $=300 \mathrm{~ms} /$ pixel at $3570 \mathrm{eV}$ for $\mathrm{S}, \mathrm{P}, \mathrm{Cd}$ and at $4100 \mathrm{eV}$ for Ca. (B) Two 1025 or three components fits (dotted line) of $\mathrm{Cd} \mathrm{L}_{\mathrm{III}}$-edge $\mu$-XANES spectra (solid line) of points 1026 of interest marked by arrows and of bulk sample; (C) Derivative of Cd L $\mathrm{LII}_{\text {-edge }} \mu \mathrm{XANES}$; (D) 
1027 Distribution of Cd ligands after normalization of the percentages to $100 \%$. The uncertainty is 1028 estimated to $\pm 10 \%$.

1029 Figure 4: Carbon assimilation in C. reinhardtii grown in TAP ${ }_{\text {EDDHA }}$ medium (labeled ${ }^{13} \mathrm{C}-[1,2]$ 1030 acetate). (A and B) ${ }^{13} \mathrm{C} /{ }^{12} \mathrm{C}$ isotope ratio images obtained by NanoSIMS using $\mathrm{Cs}^{+}$source. The 1031 analyzed fields of $256 \times 256$ pixels were, from left to right, $12 \times 12 \mu \mathrm{m}^{2}, 8 \times 8 \mu \mathrm{m}^{2}, 10 \times 10 \mu \mathrm{m}^{2}$

1032 for control conditions (A) and $12 \times 12 \mu \mathrm{m}^{2}, 10 \times 10 \mu \mathrm{m}^{2}, 10 \times 10 \mu \mathrm{m}^{2}$ for cadmium exposure 1033 conditions (70 $\mu \mathrm{M} \mathrm{Cd}$ for $48 \mathrm{~h})(\mathrm{B})$, scale bar $=2 \mu \mathrm{m}$, ROI and annotations for pyrenoid and 1034 starch plates are shown in Figure S1. (C) Impact of $70 \mu \mathrm{M}$ Cd exposure for $48 \mathrm{~h}$ on ${ }^{13} \mathrm{C}$ isotopic 1035 enrichment in the pyrenoid and in starch plates $(n=6 \pm s d)$. Isotopic distribution of carbon in 1036 starch plates obtained from $f_{\text {acetate }}$ and $f_{\mathrm{CO} 2}(\mathrm{D})$ and in starch carbon equivalent $(\mathrm{E}),(\mathrm{n}=6 \pm \mathrm{sd})$.

1037 Significant differences with respect to the control condition according to Kruskal-Wallis one1038 way analysis of variance on ranks $(\mathrm{p}<0.05)$ are indicated by an asterisk $(*)$.

1039 Figure 5: Proposed model of cadmium impact on the assimilation of carbon in 1040 Chlamydomonas reinhardtii in mixotrophic conditions. The description of the general 1041 metabolic pathways for carbon assimilation from organic (acetate) and inorganic $\left(\mathrm{CO}_{2}\right)$ sources 1042 are adapted from Johnson \& Alric (2013). Under exposure conditions, cadmium is highly 1043 sequestered in the pyrenoid by sulfur ligands, impairing the Calvin cycle. Thus, $\mathrm{CO}_{2}$ and 1044 acetate assimilation involving the Calvin cycle is limited (thin grey arrows) whereas acetate 1045 assimilation through glyoxylate cycle is favored (thick blue arrows). In addition, the 1046 anaplerotic PEPC activity could hypothetically participate in inorganic carbon fixation. Starch 1047 is accumulated in the chloroplast to prevent cellular troubles due to $\mathrm{Cd}$ stress. Finally, $\mathrm{Cd}$ is 1048 also sequestered in vacuoles, coordinated by phosphate ligands. Abbreviations: SDH, 1049 Succinate dehydrogenase; FUM, Fumarase; $M D H$, Malate Dehydrogenase; PCK, 
1050 Phosphoenolpyruvate Carboxykinase; PEPC, Phosphoenolpyruvate carboxylase; $C A H$, 1051 Carbonic anhydrase.

1052

\section{SUPPORTING INFORMATION}

1054 Supporting information is available at the publisher's web-site. Supporting information is given

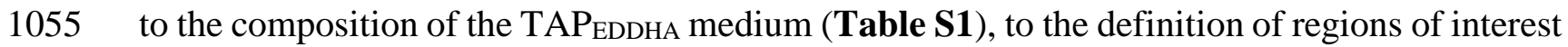

1056 (ROI) in NanoSIMS ${ }^{13} \mathrm{C} /{ }^{12} \mathrm{C}$ images for data analysis (Figure S1), and to linear combination

1057 fits (LCFs) of XANES spectra (Figure S2).

1058

1059

1060

1061

1062

1063

1064

1065

1066

1067

1068

1069

1070 
Figure 1
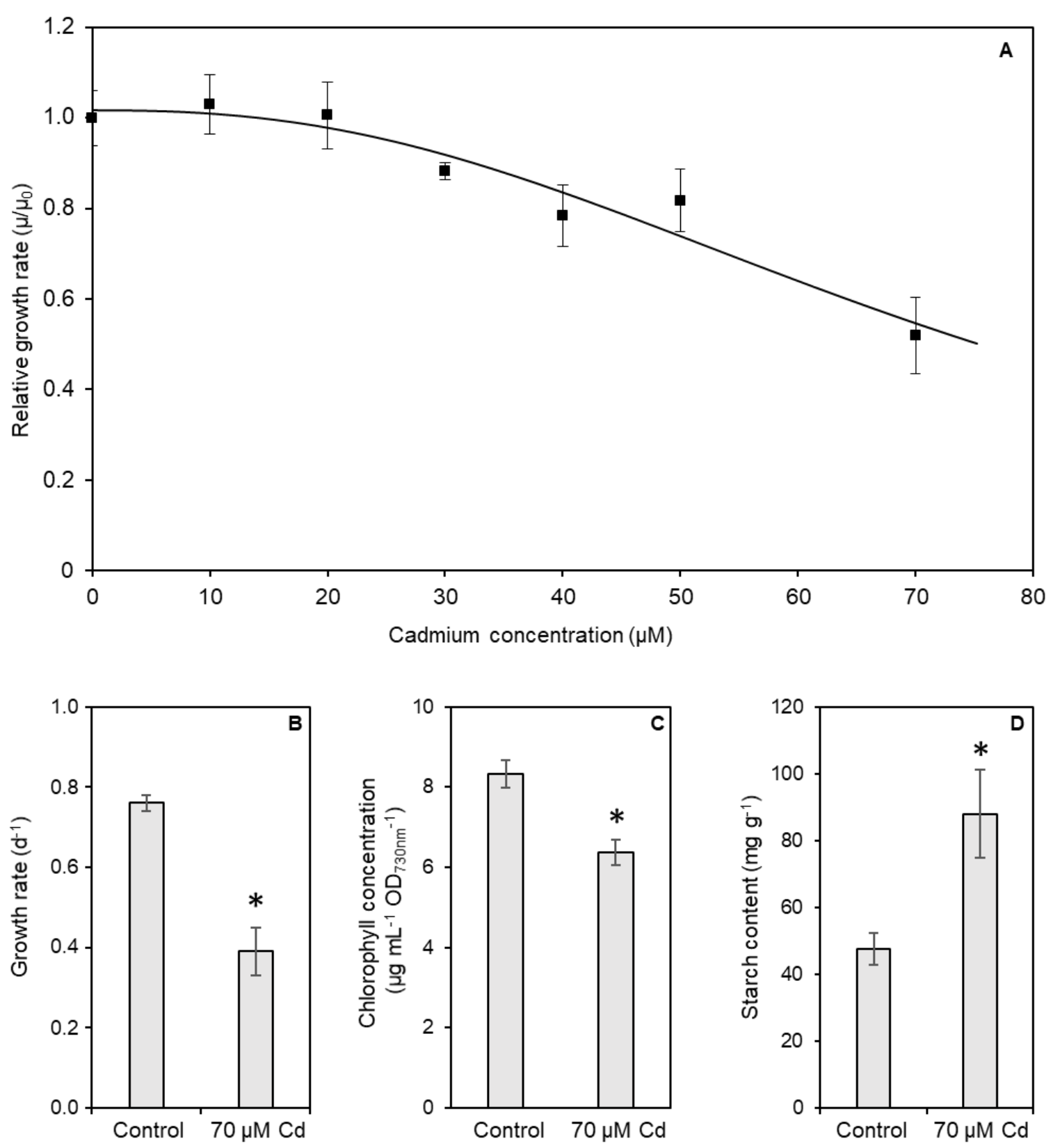

1072

1073

1074

1075

1076 
Figure 2
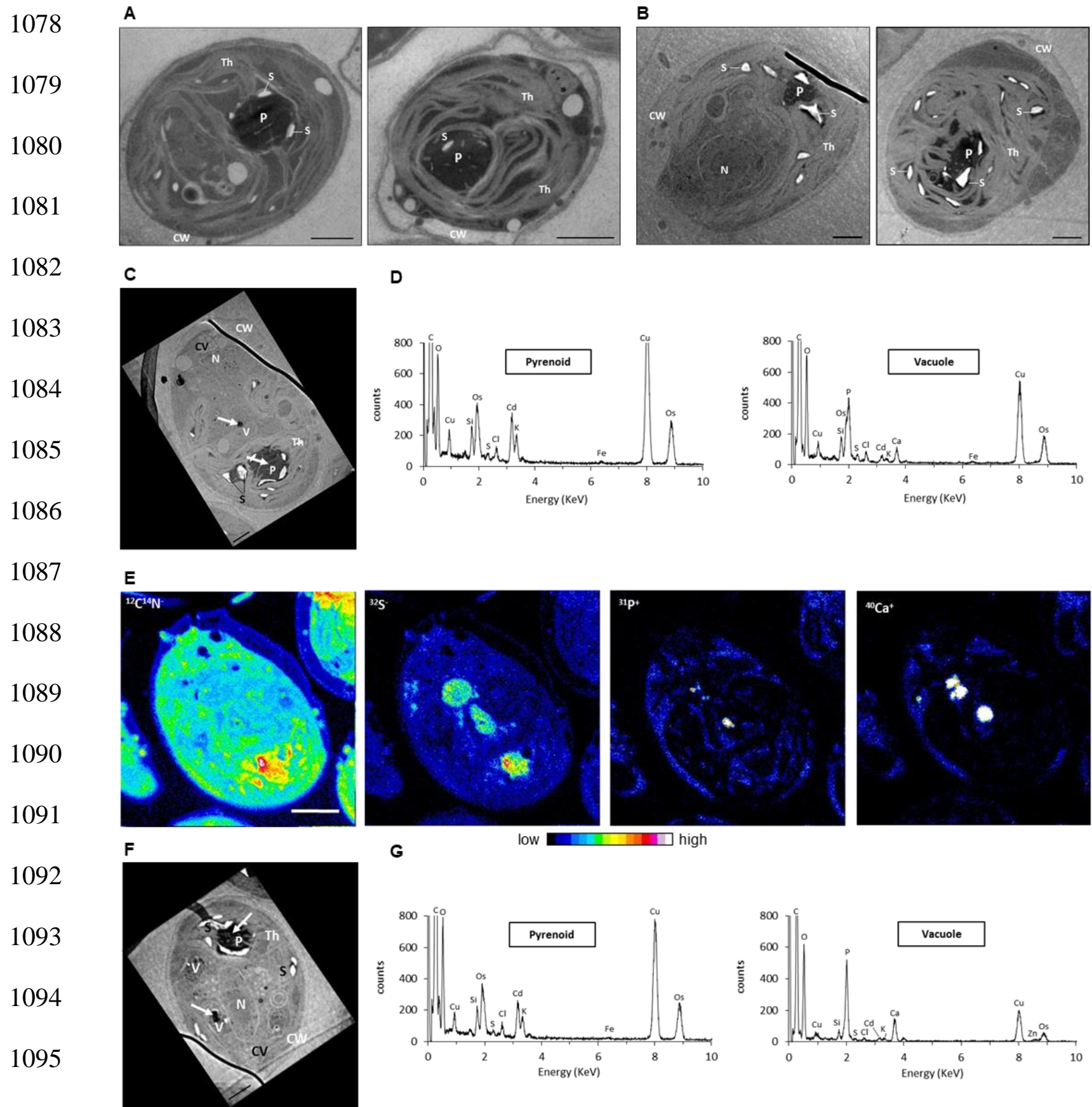

G
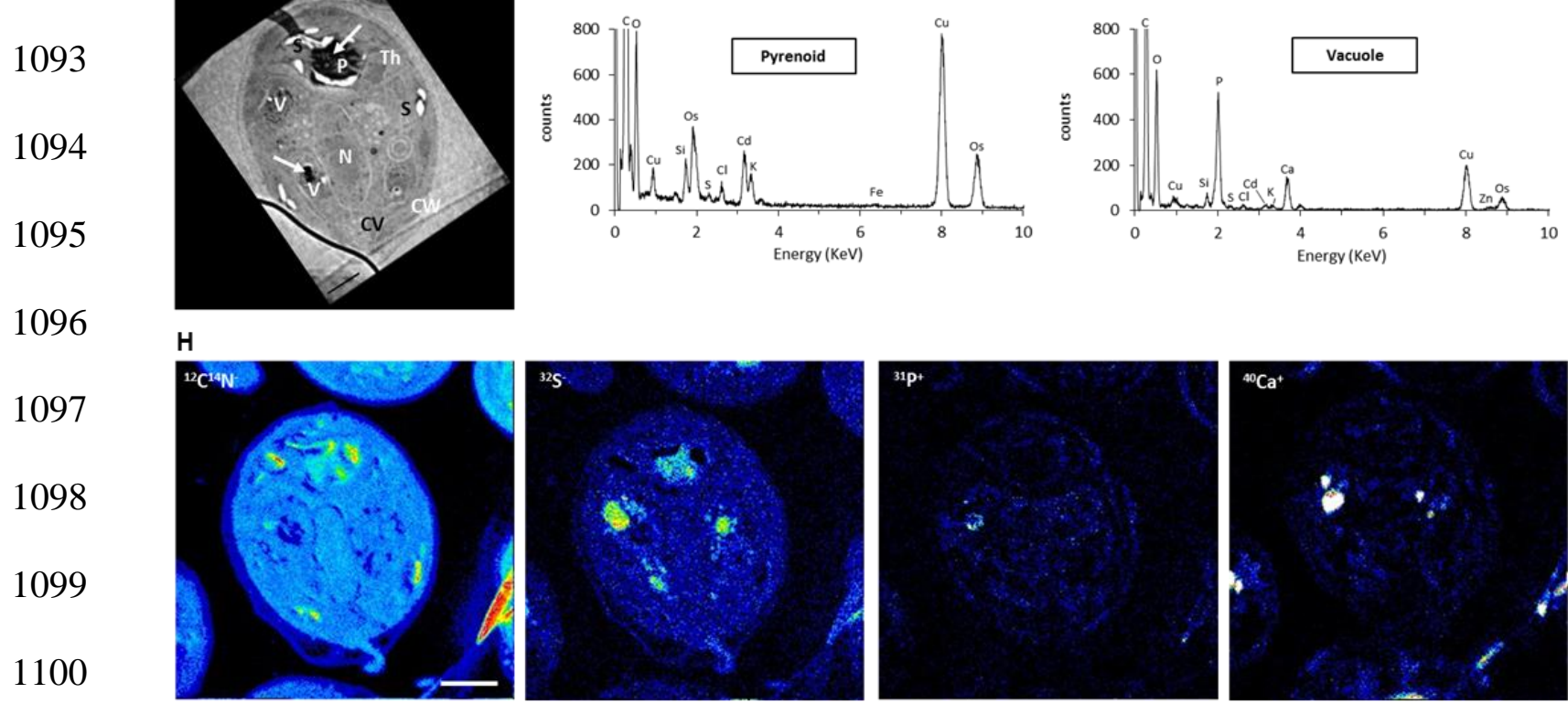

1101
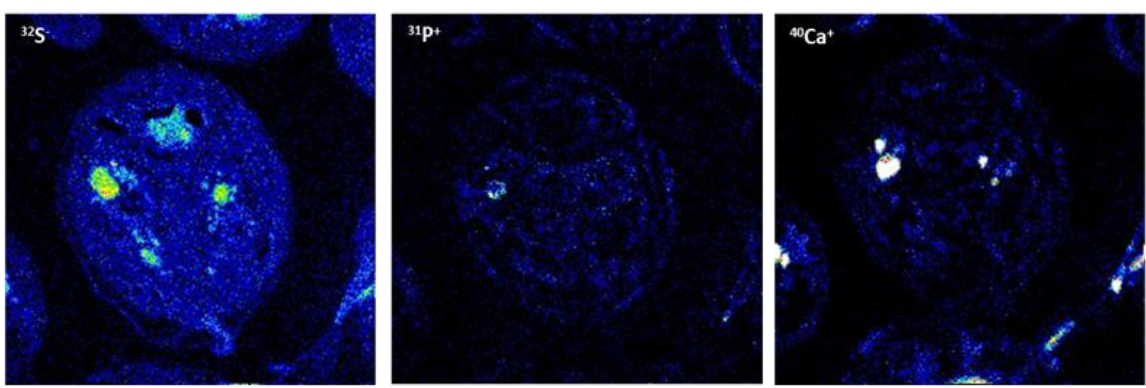

low $\square$ high 
Figure 3
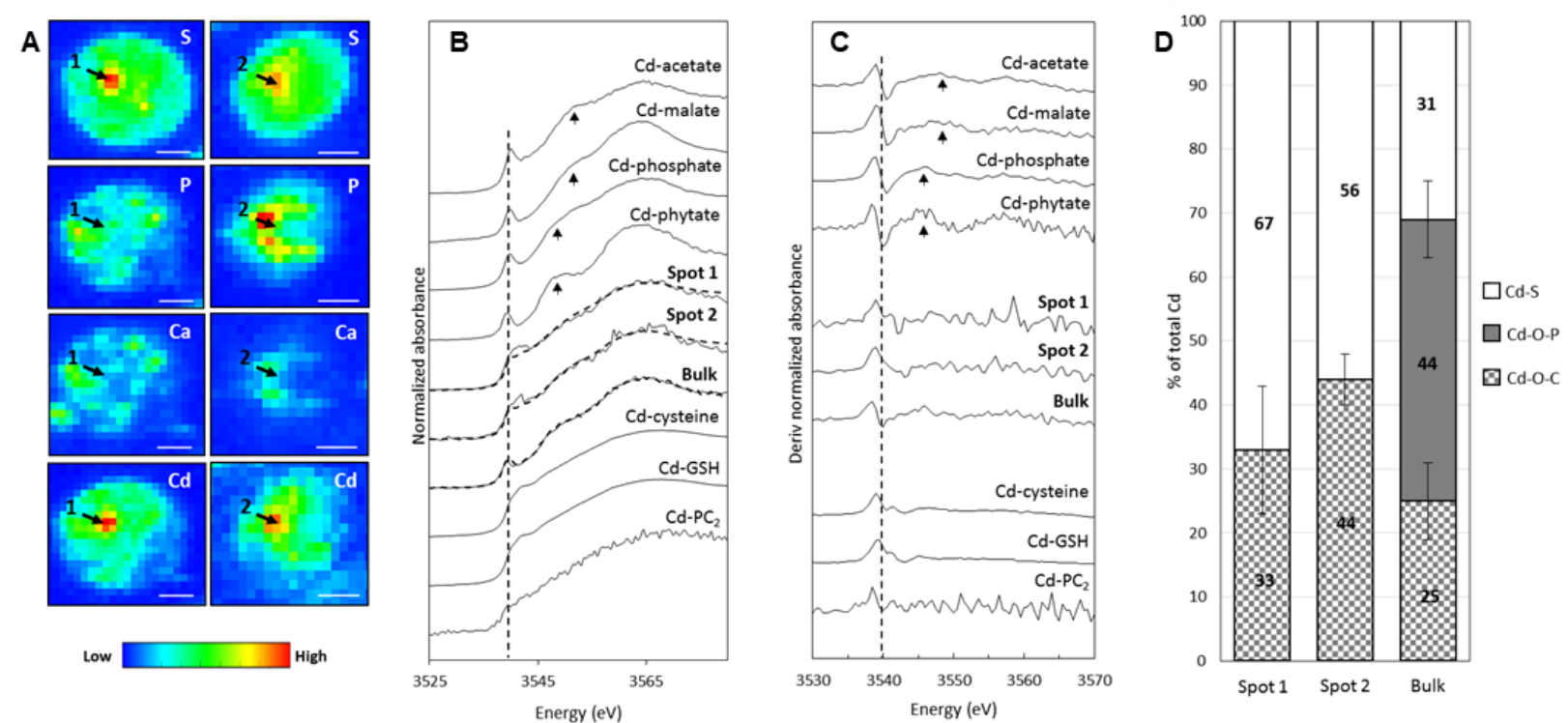

1103 
Figure 4
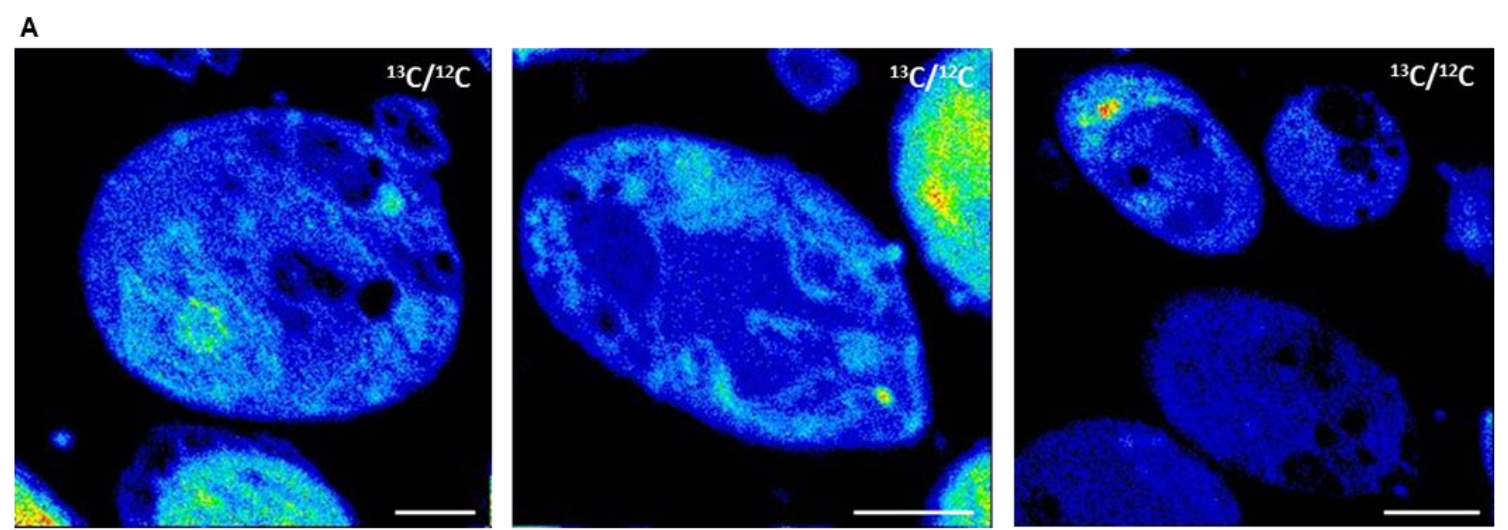

B
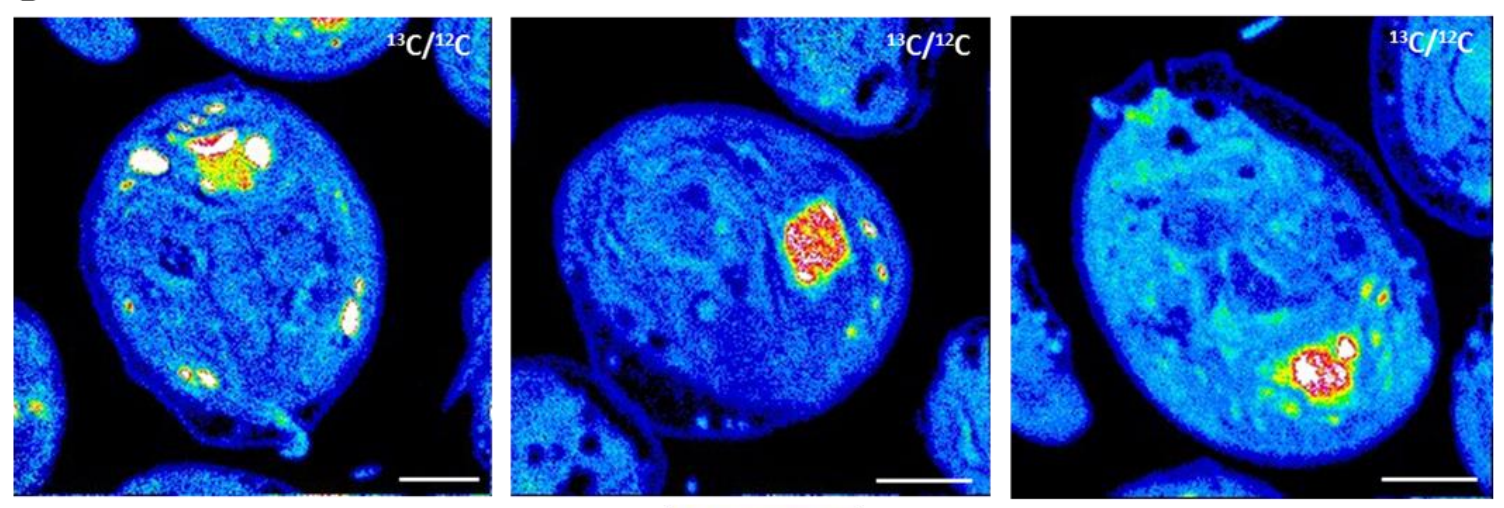

low $\square$ high
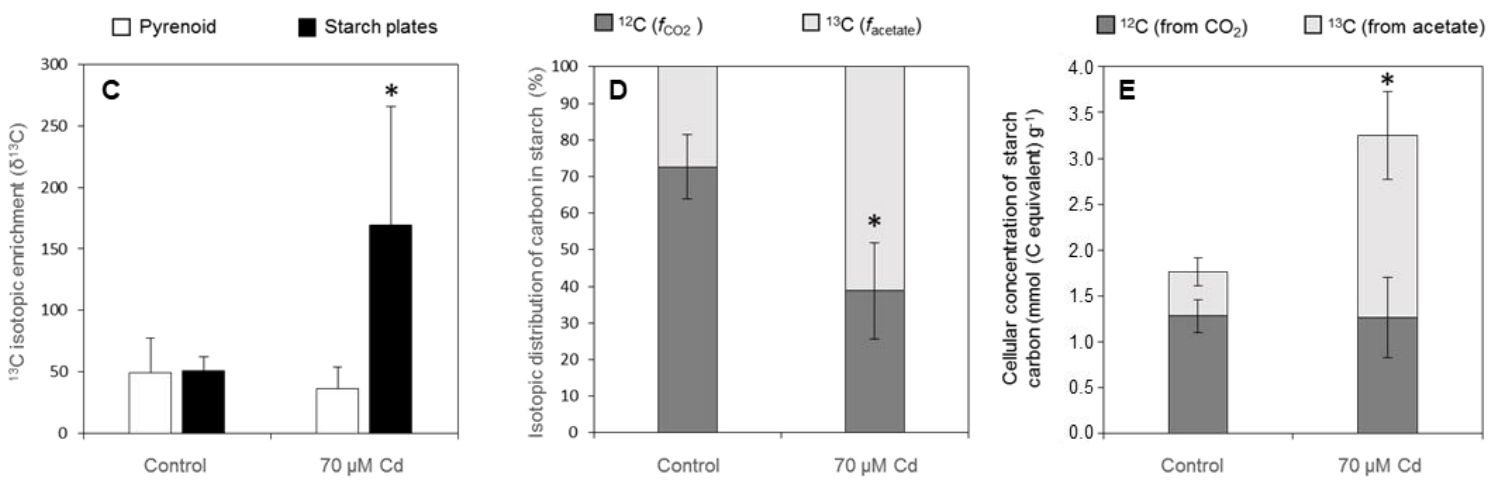

1104

1105

1106

1107

1108

1109

1110 
Figure 5

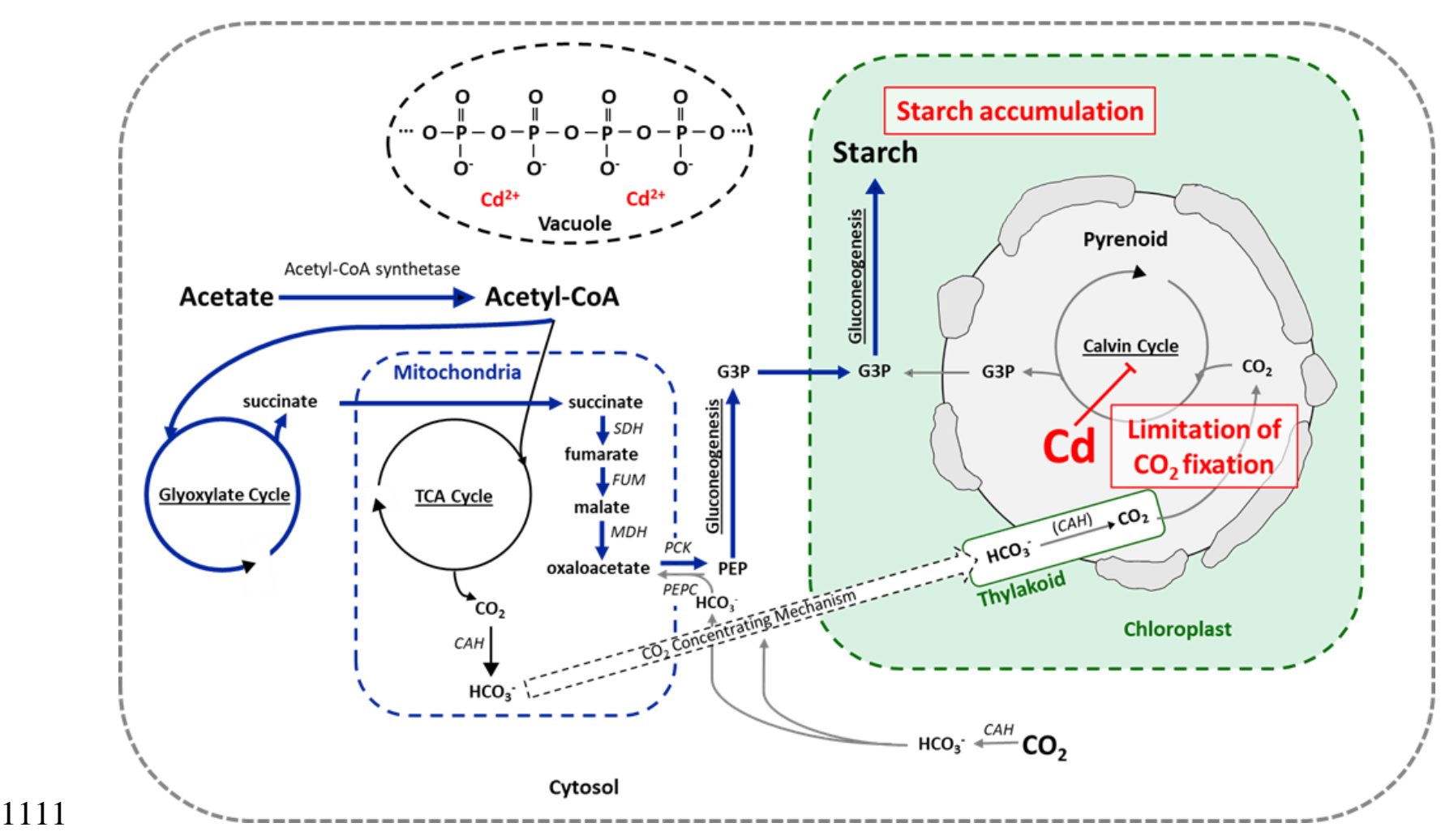

